\title{
Os Estados Unidos, o Brasil e a Guerra Fria, 1945-1960: fim do relacionamento
}

A Guerra Fria trouxe significativa mudança nos alinhamentos da política externa americana, na medida em que antigos aliados passaram a adversários e inimigos recentes se transformaram em parceiros. A Alemanha e o Japão vêm, de pronto, à mente como exemplos do último caso, enquanto que a China, antes amiga, já em 1950 se transformara em amargo antagonista. De modo menos dramático mas também com resultados profundamente negativos, durante a primeira década do pós-guerra Washington 'perdeu' o Brasil, quinto maior país do mundo e a oitava economia de mercado em 1981. Assim agindo, o governo americano praticamente garantiu o declínio, a longo prazo, de sua influência na América Latina.

Os virulentos sintomas de uma postura adversária da parte do Brasil não foram nitidamente percebidos até meados dos anos 70 , quando os dois governos se viram divergindo quanto a praticamente todas as questões internacionais, como Brasil freqüentemente encabeçando a resistência latinoamericana à política dos Estados Unidos. Dificuldades recentes, melhor exemplificadas pelo discutido Acordo Nuclear de 1975 entre o Brasil e a Alemanha Ocidental $^{1}$, pareceriam tanto mais incompreensíveis quanto o Brasil fora um aliado histórico dos Estados Unidos na América Latina, desde pelo menos a virada do século, quando a manutenção de um relacionamento especial com Washington se transformara em uma das colunas mestras da estratégia de política externa brasileira. $\mathrm{O}$ apego àquele relacionamen- to se originara da convicção brasileira de que os interesses de um Brasil luso-africano, de idioma português, eram fundamentalmente diversos daqueles de seus vizinhos indo-europeus de fala espanhola e potencialmente hostis e que a amizade americana era o melhor meio de reforçar a posição do Brasil visà-vis a América espanhola, em particular seu arquirival, a Argentina. Em troca de assistência econômica, diplomática e militar preferencial dos Estados Unidos, o Brasil atuaria como intermediário em relação a América espanhola assumindo também responsabilidades crescentes quanto à defesa do Atlântico Sul - assim concebiam a aliança os formuladores da política brasileira. Em diversas ocasiões o Brasil colaborou intimamente com os Estados Unidos, buscando consolidar o relacionamento especial. A participação em ambos os conflitos mundiais - durante a Segunda Grande Guerra o Brasil foi o único país latino-americano a mandar tropas para a Europa - caracterizou essa cooperação ${ }^{2}$. Entretanto, chegados os anos 70 , foi ficando mais evidente que o Brasil abandonara a estratégia que o havia isolado dentro da comunidade latino-americana e adotara posição de solidariedade com a América espanhola frente aos Estados Unidos. Em outras palavras, uma clara mudança política havia ocorrido.

A pergunta para o historiador é por que se verificou a mudança? Tratava-se de um resultado das condições prevalentes na década de 70 ou teriam suas causas raízes mais profundas? A resposta está 
nos primeiros 15 anos da Guerra Fria quando prioridades nacionais divergentes e conceitos conflitantes de defesa hemisférica geraram, pela primeira vez neste século, um grave choque de políticas. O resultado foi uma dramática erosão da confiança brasileira no relacionamento especial, o que preparou o caminho para uma fundamental reavaliação da política nacional em relação aos Estados Unidos, no final dos anos 50 .

O apogeu da cooperação americano-brasileira foi alcançado durante a Segunda Guerra Mundial. 0 Brasil, sob a orientação do benevolente ditador $\mathrm{Ge}$ túlio Vargas, se colocou solidamente ao lado do bloco anti-Eixo; permitiu que os Estados Unidos construíssem bases aéreas no saliente Nordeste do paíse organizassem uma ponte aérea daquela região para a Africa e Oriente Médio; colaborou no patrulhamento aéreo e naval do Atlântico Sul; forneceu materiais estratégicos e, finalmente, enviou uma força expedicionária à Europa. Washington em contrapartida, concedeu empréstimos e assistência técnica para a usina siderúrgica de Volta Redonda, deu ao Brasil substancial assistência pelo sistema de lend-lease $13 / 4$ do total concedido à América Latina), equipou e transportou a Força Expedicionária e apoiou, pela via diplomática, a bem sucedida pretensão brasileira de conseguir assento no ConseTho de Segurança da recém-criada Organização das Naçðes Unidas 3 .

A folha de serviços do Brasil durante a guerra, sobretudo quando comparada com a da Argentina, que adotou uma política obstrucionista e mesmo pro-Eixo depois de 1940, justificava e mesmo assegurava, aos olhos dos responsáveis pela política brasileira, uma intensificação do auxílio americano no pós-guerra. Esse auxílio parecia tanto mais vital na atmosfera turbulenta da Guerra Fria, a qual, do ponto de vista brasileiro, ameaçava degenerar, a qualquer momento, em choque armado ${ }^{4}$. $\mathrm{Na}$ América do Sul surgia a necessidade de conter o regime de Juan Perón, questão de implicações aparentemente sérias, uma vez que o intenso esforço armamentista argentino e sua ousada ofensiva diplomática e comercial nos vizinhos países hispano-americanos pareciam dirigidos, essencialmente, contra o Brasil ${ }^{5}$.

Os dirigentes brasileiros entendiam a aliança com os Estados Unidos como uma maneira de enfrentar esses graves desafios ${ }^{6}$. Essa interpretação das tendências internacionais naturalmente fazia com que atribuíssem pripridades maior à aquisição de material bélico e conversações a nivel de estadosmaiores, no final da guerra, levara-os a crer que Washington continuaria a colaborar na modernização das Forças Armadás brasileiras?. Mas o Departamento de Estado, agora, se opunha a gastos mili- tares 'excessivos' em países latino-americanos que careciam de capital para seu desenvolvimento econômico e social. Washington desejava estimular 0 emprego de equipamento militar americano na América Latina mas não queria que os gastos excedessem os limites que os planejadores norte-americanos consideravam suficientes para garantir a segurança interna e a defesa hemisférica. Além disso, as novas armas atômicas punham em dúvida conceitos de defesa por meio de forças convencionais. Outra consideração do Departamento de Estado era a possibilidade de que a ajuda militar pudesse ser usada para fortalecer regimes antidemocráticos ${ }^{8}$.

Mais do que escassa quantidade de material de segunda mão que recebiam, irritou os dirigentes brasileiros o fato de que Washington, em seguida à longa disputa com Buenos Aires sobre a influência alemã na Argentina, decidiu, em 1947, incluir aquele país no modesto programa de assistência militar, em pé de igualdade com os outros países latino-americanos $^{9}$. Do ponto de vista do Departamento de Estado, o desafio mundial comunista exigia a solidariedade hemisférica e isso significava uma reaproximação com a Argentina. Esta perspectiva preocupava as autoridades brasileiras desde a vitória eleitoral de Perón, no ano anterior. Em diversas ocasiões elas tinham alertado Washington para o fato de que aquele regime era uma ameaça à estabilidade da América do Sul e insistido em que a superioridade militar brasileira do momento fosse preservada com assistência americana ${ }^{10}$. Desorientado pelos persistentes sintomas do que considerava uma contemporização americana em relação a Perón, o ltamarati, em 1948. interpelou o Embaixador Herschel Johnson sobre "qual a posição dos Estados Unidos em relação ao Brasil". Johnson respondeu que Washington não podia "tomar partidos abertamente" em suas relacões com a América Latina, resposta que mais tarde the valeu elogio do Departamento de Estado. O Departamento não só rejeitou nova proposta brasileira de uma aliança geral, que implicaria em substancial assistência militar americana, mas se negou, até mesmo, a admitir publicamente que tinham um interesse especial na defesa do Brasil11.

Se os governantes brasileiros se sentiam ludibriados pela passividade de Washington no campo da assistência militar, ficaram atordoados ante a reticência americana na área de ajuda econômica. A receptividade demonstrada por Washington durante a guerra no tocante às ambições industriais do Brasil havia reforçado o otimismo nacional quanto à colaboração dos Estados Unidos no pós-guerra ${ }^{12}$. Logo depois de assumir o Governo em 1946, o Presidente Eurico Gaspar Dutra enviara carta pessoal a Harry Truman pedindo auxílio para a intensificação do desenvolvimento brasileiro. Manifestações de 
boa vontade do Departamento dé Estado e de Truman, pessoalmente, reforçaram as esperanças do Brasil e levaram o Itamarati, em março daquele ano, a pedir um empreséstimo de US\$ 1 bilhão, pelo prazo de cinco anos. Essa ajuda, dizia o Itamarati, seria a "pedra angular" da administração do Presidente Dutra. O empréstimo a longo prazo para o desenvolvimento jamais se concretizaria. O Brasil recebeu apenas US\$ 46 milhões em 1946 e US\$ 90 milhões no ano seguinte, fatos que geraram perplexidades e ressentimentos no Brasil. Num episódio revelador, ocorrido em meados de 1947, o embaixador brasileiro "teve um rompante" no Departamento de Estado e acusou amargamente o governo americano de não dar ao Brasil a assistência que este merecia ${ }^{13}$.

Em parte, cabia as próprias autoridades brasileiras a culpa pela demora no processamento de empréstimos pois, muitas vezes, deixavam de fornecer - geralmente por ineficiência administrativa - os dados e números exigidos pelos organismos financiadores. Por outro lado, os negociadores brasileiros continuavam querendo operar nos termos da aliança do tempo da guerra; por causa do tamanho, potencial e localização estratégica do Brasil contavam com que a boa vontade do Executivo em Washington eliminasse os entraves burocráticos, como acontecera quando Franklin Delano Rooseveldt ocupava a Casa Branca ${ }^{14}$. Mas a situação internacional e as circunstâncias políticas nos Estados unidos haviam mudado desde a guerra. Os planejadores políticos e os administradores americanos não mais trabalhavam sob a pressão de maquinações nazistas na América do Sul e de ameaças potenciais ao Canal do Panamá e à navegação no Atlântico Sul. Assim, os pedidos brasileiros de empréstimos repetidamente esbarravam em exigências técnicas e, no ano de 1948, o Brasil não recebeu qualquer financiamento americano ${ }^{15}$.

Entretanto, o fator mais importante para o insucesso brasileiro na obtenção da cooperação econômica desejada era a convicção de Washington de que as necessidades brasileiras de desenvolvimento Seriam melhor atendidas pelo capital privado. O governo brasileiro, para atrair investidores estrangeiros, deveria observar, rigorosamente, um programa de liberalismo econômico, renunciando à estatização e ao nacionalismo. Assim, o Departamento de Estado se opôs, desde o primeiro momento, à política brasileira de petróleo, que previa restrições à participação estrangeira. Em julho de 1948, tanto o Embaixador William Pawlei quanto o Secretário do TeSouro John Snyder dissertaram perante platéias brasileiras sobre a necessidade de legislação liberal para encorajar os investidores estrangeiros. Quando, no ano seguinte, em Paris, o Ministro do Exterior, Raul Fernandes, conversou com o Secretário de Estado George Marshall sobre o que o Brasil precisava para o seu desenvolvimento, saiu "com as mãos vazias" e com recomendações sobre a necessidade de recorrer ao capital privado. Os membros americanos da Comissão Técnica Brasil-Estados Unidos - criada em 1948, sob a presidência de John Abbink, para identificar pontos de estrangulamento na economia brasileira - levaram o mesmo recado para o Rio de Janeiro. Truman, mais tarde, considerou o relatório final da Comissão - que ressaltava a importância do capital privado estrangeiro - "muito útil" para a formulação de uma política em relação ao Brasil ${ }^{16}$. Isso queria dizer, evidentemente, que o ônus do desenvolvimento, na opinião de Washington, cabia exclusivamente ao governo brasileiro ${ }^{17}$.

Os formuladores da política americana estavam também preocupados com a reconstrução européia e a remuneração da Asia e comparativamente, os problemas do Brasil e do restante da América Latina pareciam menos urgentes. "A situação", declarava, canhestramente, o Embaixador Johnson à imprensa brasileira. "podia ser graficamente representada como um caso de varíola na Europa competindo com um resfriado na América Latina". O Departamento do Tesouro, ante as reclamaçð̃es brasileiras, se limitava, essencialmente, a expressar a esperança de que a recuperação da Europa viesse a beneficiar indiretamente o Brasil e Dean Acheson, que se tornou Secretário de Estado em 1949, tendia a excluir, por completo, a América Latina de quaisquer consideraçðes políticas mais abrangentes. O Brasil recebeu US\$ 105 milhð̋es em empréstimos do Banco de Exportação e Importação - Eximbank durante o período de 1946 a 49, bem como assistência técnica da Comissão Abbink e tanto Acheson quanto o secretário-adjunto, Edward Miller Jr., publicamente citaram este auxílio como prova de que as alegaçð̃es de abandono pelos americanos eram infundadas ${ }^{18}$.

Se o Plano Marshall refletia a dimensão do compromisso de Washington com a defesa da Europa, aos olhos do Brasil ele representava o descaso americano quanto às necessidades e aspirações brasileiras. O ponto focal da questão era que o Plano parecia relegar o Brasil ao papel de supridor colonial de matérias-primas. Embora os porta-vozes brasileiros reconhecessem a natureza do desafio com que se defrontava o Ocidente e, mesmo, defendessem uma firme tomada de posição contra o expansionismo soviético, insistiam, cada vez mais ardorosamente, em que os problemas do Brasil também estavam ligados à segurança hemisférica e podiam ser melhor resolvidos por meio da cooperação oficial americana no processo de industrialização brasileiro ${ }^{19}$. Especialmente angustiante para os dirigentes brasileiros era o aparente estímulo que os dólares do 
Plano Marshall davam ao desenvolvimento das possessões francesas e inglesas na Äfrica, concorrentes econômicas do Brasil ${ }^{20}$. Raul Fernandes expressou a insatisfação do governo em conversa mantida com Johnson, às vésperas de viajar com o Presidente Dutra a Washington, em 1949 e lá voltou ao assunto com as autoridades americanas. Recordando-Ihes as contribuições brasileiras para a vitória na II Guerra Mundial, o Ministro do Exterior se referiu à ameaça argentina e se queixou de que os Estados Unidos estavam enviando "bilhões" para a Europae indiretamente para a Affrica e outras regiões coloniais. Reclamando para o Brasil "tratamento discricionário favorável", Raul Fernandes repeliu sugestão de um funcionário do Departamento de Estado de que o capital privado era a solução e afirmou que um empréstimo oficial de US\$ 600 milhões, com prazo de seis anos, seria razoável21.

Quando a visita do Presidente Dutra deixou de produzir os resultados financeiros desejados Washington, naquele ano concedeu ao Brasil apenas US\$ 46 milhões em créditos do Banco de Exportação e Importação - cresceu o ressentimento brasileiro. Em janeiro de 1950, Raul Fernandes enviou a Johnson um memorandum em que expressava a "maior apreensão" quanto à concorrência africana e, mais uma vez, acusava Washington de ignorar o Brasil. Johnson chamou a atenção do Departamento de Estado para o fato de que o Brasil era o país mais importante da América Latina e Abbink encareceu uma solução para o "aparente impasse" nas relações com o Brasil. "Eles estão absolutamente convencidos" escreveu Abbink a Miller "de que, como um dos aliados ativos dos Estados Unidos em ambas as guerras, o Brasil deveria ter sido beneficiário de recursos do Plano Marshall em igualdade de condições com nossos aliados europeus e certamente antes que alguns de nossos inimigos (itália, Alemanha e Japão) recebessem ajuda"22. Essas advertências poucos resultados produziram; pelo contrário, surpresas desagradáveis aguardavam os planejadores brasileiros.

Em primeiro lugar, em princípios de maio, quatro meses depois de receber o memorandum de Raul Fernandes, o Departamento de Estado deu sua resposta por intermédio do contrafeito Embaixador Johnson. O memorandum americano negava que o estímulo à produção agrícola africana fosse afetar o abastecimento internacional, já que o objetivo era um aumento do consumo local e argumentava que, por força do Plano Marshall, compras estimadas em cerca de US\$ 760 milhões tinham sido feitas na América Latina. O que, no entanto, mais ofendeu Raul Fernandes foi o anexo à nota: uma listagem dos créditos concedidos ao Brasil pelo Banco Exportação e Importação durante a década dos $40^{23}$. Um segundo e mais forte abalo se verificou no mesmo mês, sob a forma de notícias de que a Argentina estava negociando um empréstimo em Washington. O próprio Truman, embora "muito satisfeito" como andamento dos entendimentos com as autoridades argentinas, anteviu repercussð̃es sobre as relaçð̋es com o Brasil, mas o Departamento de Estado, preocupado em levar Péron a um recuo em sua política obstrucionista, queria, apesar de tudo, que o empréstimo fosse concedido a qualquer custo ${ }^{24}$. Os observadores brasileiros ficaram estupefatos ante 0 anúncio, feito em maio, de que o regime de Perón obtivera um empréstimo de US\$125 milhões quase tanto quanto recebera o Brasil durante todo 0 governo Presidente Dutra. Influentes editorialistas brasileiros, sarcasticamente, condenaram a generosidade de Washington para com o ditador argentino, ao mesmo tempo em que Raul Fernandes, profundamente contrariado, fazia o Embaixador Maurício Nabuco, em Washington, advertir o Departamento de Estado sobre as conseqüências danosas de novos atrelos na concessão de auxílio ao Brasil ${ }^{25}$. Nessas circunstâncias, a divulgação em Washington do relatório de uma subcomissão do Senado, que responsabilizava os países produtores por drástico aumento dos preços do café e recomendava represálias, esfregou sal na ferida. Enquanto comentaristas internacionais no Brasil, atacavam os Estados Unidos, Nabuco dizia a Acheson que "pela primeira vez em minha vida" estava preocupado com as relações entre os dois países ${ }^{26}$. No momento em que, no Brasil, cresciam a amargura e desilusão, os exércitos da Coréia do Norte cruzavam o paralelo 38 e levaram Truman à decisão de usar tropas americanas para resistir à invasão. O Conselho de Segurança da ONU condenou a agressão e pediu aos Estados-membros que auxiliassem a Coréia do Sul. Durante as tensas semanas que se seguiram, enquanto tropas sul-coreanas e americanas vergavam sob o peso da ofensiva de Pyongyang, aumentava em Washington o desejo de assegurar ativa cooperação militar e econômica brasileira, em parte, porque tal cooperação serviria de exemplo a outros países sulamericanos. Nesse sentido, a 14 de julho, o Governo americano, como porta-voz das Forças da ONU, levou o Secretário da ONU a informar o Governo brasileiro de que precisava "urgentemente" de tropas ${ }^{27}$. Ao mesmo tempo, numa tentativa de aplacar a irritação brasileira quanto aos rumos da política americana no pós-guerra, Washington apoiou decididamente a candidatura do Brasil à reeleição para 0 conselho de Seguranca e fez com que o Banco de Exportação e Importação liberasse US $\$ 25$ milhð̋es para a aquisição de equipamento para Volta Redonda ${ }^{29}$.

Tanto o governo quanto a opinião pública brasileiros endossavam a ação da ONU na Coréia ${ }^{30}$ mas 
a capacidade de iniciativa do Presidente Dutra se achava severamente limitada. Restavam-lhe poucos meses de mandato e não podia comprometer seu sucessor num ambicioso envolvimento militar no estrangeiro. Além disso a mobilização americana logo começou a criar dificuldades para o setor de manufaturados brasileiros, altamente dependente de fornecedores americanos para a aquisição de combustíveis e de matérias-primas industriais ${ }^{31}$. Estes problemas realçavam a necessidade de maior auto-suficiência nacional, o que, por sua vez, reavivava na lembrança do governo e do público a relutância de Washington em auxiliar o Brasil no seu desenvolvimento ${ }^{32}$. Em conseqüencia, o Itamarati responderia interlocutoriamente ao pedido inicial do Conselho de Segurança, declarando apenas que o Brasil se desincumbiria de suas obrigacões nos termos da carta da ONU, na "medida de seus meios". $\mathrm{O}$ apelo de Washington, de 14 de julho, deparou com igual cautela. Convocado pelo Presidente Dutra, o Conselho de Segurança Nacional - CSN decidiu que o Brasil não poderia fornecer tropas terrestres a poucas semanas das eleições, decisão que, em si mesma, já refletia a fragilidade do relacionamento especial. Daí que, em sua resposta formal à ONU, o Itamarati não falou de tropas mas apenas reiterou que o Brasil estava pronto a discutir formas de prestar "auxílio compativel com os meios de que dispõe"

Raul Fernandes, em resposta polidamente sarcástica, dada em agosto, à nota recebida do Departamento de Estado em maio, recordava a Washington que esses meios não eram tão abundantes quanto poderiam ser. O Ministro do Exterior rejeitou o argumento de que o auxílio americano à África estimulava apenas o consumo local e não as exportacões e assinalou que a fatia do Branco nas compras do Plano Marshall tinha sido "muito magra". Em seguida afirmou que a questão dos créditos recebidos pelo Brasil nada tinha a haver com a da concorrência africana. "O Governo brasileiro não esquece os benefícios com que o Brasil tem sido contemplado através de empréstimos do Banco de Exportação e Importação" afirmou rispidamente. "Não podia esquecê-los, nem era preciso que fossem lembrados pois os vencimentos de juros e amortizaç̃es, em datas estabelecidas, constituem um momento permanente". O Brasil tinha apoiado os aliados durante a última guerra, disse Raul Fernandes, enquanto outros países - e aqui ele se referia à Argentina - permaneciam neutros. "Esta é uma comparação", concluiu acusadoramente, "que vem sendo muito esquecida" 34 .

Defrontado com uma emergência, o Departamento de Estado rapidamente tentou apaziguar o governo brasileiro informando a Nabuco que desejava iniciar conversações sobre auxílio econômico adicional e propondo um acordo de assistência técnica bilateral, no âmbito do novo programa do Ponto 4. Aguilhoado pelo pedido feito, em setembro, pelo Estado Maior Conjunto, de "providências urgentes" no sentido de assegurar tropas sul-americanas para a Coréia e cônscio de que a reação "apática" do Brasil estava, provavelmente, influenciando outros governos, Miller também promoveu, no mês seguinte, um encontro de Nabuco com Truman. Ao ouvir do enviado brasileiro as queixas de dificuldades na obtenção de empréstimos e na cessão de dois cruzadores que seu governo desejava, Truman assegurou a Nabuco seu desejo de manter um "singular e especial relacionamento" com o Brasil e disse que "se interessaria pessoalmente" pelos pedidos de empréstimos e pelas negociacões sobre os cruzadores ${ }^{35}$.

As bênçãos de Truman encorajaram o Departamento de Estado a tomar iniciativas, ao mesmo tempo em que a melhoria considerável da situacão militar tornava menos arredios os organismos de financiamento. Miller conseguiu, assim, um compromisso preliminar de US\$ 250 milhões do BIRD em favor do Brasil e o Banco de Exportacão e Importação deu esperancas de liberar outros US\$ $100 \mathrm{mi}-$ Ihões, enquanto Acheson, a 19 de outubro, comunicava a Truman que o assunto dos cruzadores agora "estava encaminhado". Naquela mesma semana os dois Governos acordavam constituir a Comissão Mista Brasil-Estados Unidos para o Desenvolvimento Econômico ${ }^{36}$.

Em princípios de novembro, dramáticos acontecimentos no Extremo-Oriente tornavam um engajamento do Brasil na Coréia simultaneamente mais difícil e mais necessário: a República Popular da China, para impedir o colapso total do regime da Coréia do Norte, interveio maciçamente e logo empurrou as forças da ONU pela península abaixo. A 18 de novembro, Acheson instruia os Embaixadores americanos na América Latina a redobrarem esforcos para obtenção de tropas. Enquanto uma nuvem de renovada tensão e ansiedade se abatia sobre os Estados Unidos e uma mobilização acelerada se revelava urgente, profundas incertezas imperavam nos meios financeiros e comerciais. Segundo as palavras de um assessor de Johnson, Miller se via obrigado a advertir a América Latina de que, "razões menores se anunciam e se espera que a América Latina compartilhe desses sacrificios". Miller insinuou o mesmo em coversa com Nabuco, a 12 de dezembro, e no dia seguinte comentou, reservadamente, que, embora esperassem maior colaboracão do Brasil, antecipava "terriveis dores de cabeça" na tentativa de atendimento das necessidades brasileiras de importação. Miller constatou ainda que não houvera progresso no encaminhamento dos empréstimosao 
Brasil, simplesmente porque o Departamento do Tesouro, à vista da crise, se opunha a novos compromissos $^{37}$.

A convocação feita por Acheson, em dezembro, de uma reunião extraordinária de Chanceleres do hemisfério para discutir medidas de emergência para a mobilização refletiu o novo sentido de urgência que inspirava a política em relação à América Latina. O Departamento de Estado esperava transformar o Brasil, "pedra de toque" de seu programa na área, em um aliado "ativo". A decisão tomada, em fins daquele ano, de consultar Getúlio Vargas - que acabava de alcançar retumbante vitória em sua campanha pela reeleição - sobre a agenda da conferência foi uma tentativa de demonstrar ao Presidente Brasileiro a posição singular que o seu país ocupava nos planos dos Estados Unidos. Maso Brasil, agora, encarava com profundo ceticismo o apelo de Washington para uma cooperação especial. Não repetiria os erros do último conflito e insitiria, desta vez, em rigorosa e imediata reciprocidade, prometia João Neves da Fontoura, o novo Ministro do Exterior. Sua resposta a uma nota de Johnson sobre a agenda da conferência se constituiu em cândida advertência: o Brasil cooperaria - embora nada se dissesse sobre o envio de tropas à Coréia - mas só se os Estados Unidos garantissem os créditos, maquinarias e matérias-primas necessários à aceleração da industrialização brasileira e à exploração de suas reservas de petróleo e carvão. Negociaçðes bilaterais sobre esses pontos deveriam ter lugar em fevereiro, dizia Joåo Neves, antes portanto da conferência, prevista para Wașington, em fins de março39.

Para Miller a resposta de João Neves conferia "renovada significação e urgência" ao tema do auxílio. "É imperativo para o futuro de nossas relaç̃es com o Brasil", Miller advertiu Acheson, "que se dê resposta pronta às propostas do Presidente Vargas". Miller embarcou para o Brasil, em fevereiro, para concluir as negociações. Tinha presente a pressão de Washington para a obtenção de uma divisão completa de tropas brasileiras e por isso ressaltou para as autoridades brasileiras a gravidade da situação na Coréia, o imperativo daí resultante da mobilização geral dos Estados Unidos e a necessidade de materiais estratégicos e de tropas brasileiras. O Brasil cooperou, em uma situação de emergência, durante a ll Guerra Mundial, lembrou João Neves, mas não colhera os benefícios do pós-guerra. "Se Washington tivesse elaborado um plano de recuperação para a América Latina semelhante ao Plano Marshall para a Europa", disse João Neves, "outra seria a situação atual do Brasil e, provavelmente, muito maior poderia ser a nossa cooperação na emergência atual". Miller só pôde renovar a promessa de que - BIRD disporia de US\$250 milhões para projetos de desenvolvimento aprovados pela futura Comissão Mista Brasil-Estados Unidos, mas Getúlio Vargas insistiu em que essa importância fosse considerada apenas como ponto de partida. O emissário americano deixou o Brasil com a promessa de que 0 país procuraria aumentar suas exportações de materiais estratégicos mas não conseguiu qualquer compromisso no tocante ao envio de tropas ${ }^{40}$.

As divergências quanto aos conceitos de segurança hemisférica ficaram nitidamente evidenciadas durante a reunião de Chanceleres. Na sessão inaugural, de 26 de março, João Neves defendeu um novo pacto com a América Latina como o meIhor meio de armar o hemisfério para enfrentar o desafio soviético ${ }^{41}$, estabelecendo assim a tônica dos debates e surpreendendo os delegados americanos que contavam com o Brasil para encaminhar as discussões no sentido da imediata contribuição econômica e militar ao esforço de guerra. Marshall, já então Secretário da Defesa, tinha, pouco antes, pedido a Acheson que fizesse um "sério esforço" para obter tropas latino-americanas e o Departamento de Estado havia estabelecido como prioritária "uma contribuição brasileira de grandes proporçðes". Mas, agora, João Neves, que fora eleito presidente do Comitê Econômico, estava transformando a conferência em um foro para a advocacia do desenvolvimento a longo prazo em vez da rápida mobilização. "De todos os problemas com que se defronta o governo na conferência", dizia um memorandum do Departamento de Estado, datado de 31 de março, "o maior, de importância tal que poderia comprometer o sucesso da reunião, é a diferença de filosofias entre o Brasil e os Estados Unidos" ${ }^{\prime 2}$.

Durante negociações bilaterais paralelas, João Neves e seus assessores se mantiveram irredutíveis. Quando Averell Harriman, assessor especial de Truman, repetiu que as necessidades de defesa militar exigiam prioridade e que, "dentro de dois anos", Washington poderia voltar a cogitar do desenvolvimento econômico da América Latina, João Neves insistiu na industrialização brasileira concomitante, ressaltando a necessidade de auxílio especial para a construção de refinarias de petróleo. Acheson pressionou João Neves quanto à cooperação militar, oferecendo treinamento, equipamento e transporte para uma divisão brasileira, mas João Neves depois de criticar o Governo americano pela venda de cruzadores à Argentina ao mesmo tempo em que transferia duas dessas belonaves ao Brasil, disse apenas que submeteria o assunto ao Presidente Vargas enquanto negociações militares preliminares se realizavam em Washington. Retrospectivamente, Acheson se daria conta de que João Neves fora apenas "mais indireto e fabiano" do que seu colega mexicano, que rejeitaria frontalmente proposta 
semelhante. Á época, no entanto, as reações de João Neves foram consideradas encorajadoras e Acheson cuidou que a resposta de Truman a uma carta do Presidente Vargas, trazida por João Neves, contivesse renovado apelo para o envio de tropas terrestres ${ }^{43}$. Nabuco informou seu governo de que os planejadores americanos se impacientavam com a inação brasileira; daí ter Getúlio Vargas reiterado a Johnson, em julho, seu desejo de cooperar, muito embora fosse claro não existir entusiasmo no Governo brasileiro por uma empreitada coreana. O General Pedro Aurélio de Góes Monteiro, Chefe do Estado Maior das Forças Armadas, advertiu o Conselho de Segurança Nacional, em maio, de que "de modo algum" tropas podiam ser enviadas ao exterior sem demorados preparativos e novo equipamento e Getúlio Vargas, pessoalmente, alimentava profundos ressentimentos, que deixou transparecer em bilhetes dirigidos ao Chefe de sua Casa Civil, o nacionalista extremado Lourival Fontes. "Lutamos na guerra passada e fomos inteiramente esquecidos e recusados na partilha dos despojos". Getúlio se dispôs tão somente a enviar Goés Monteiro a Washington para conversações; instruiu o General a reiterar apenas que o Brasil não podia colaborar eficazmente até que recebesse amplo auxilio econômico. O objetivo da viagem de Goés era, como Lourival Fontes candidamente descrevia, ganhar tempo ${ }^{44}$.

A situação se tornara, de fato, irreconciliável quando Goés chegou a Washington em julho. Pressentindo a possibilidade de o Brasil tergiversar, o Departamento de Estado já advertira duas vezes as autoridades brasileiras quanto à necessidade de rápidos resultados da missão Goés Monteiro. A vacilação brasileira era frustante, se queixava Miller, na medida em que aquele país "era a chave para a questão da América Latina". Goés percebeu logo que a cooperação militar completa era "vital" para os americanos mas suas instruções eram para ressaltar os "fatores econômicos básicos" que impediam tal cooperação. "A situação aqui", escreveu depois de seus primeiros encontros com Acheson "é bem diferente da de dez anos atrás, quanto ao grau de confiança e de mútua simpatia entre o Brasil e Estados Unidos". As táticas dilatórias de Goés Monteiro logo levaram o Departamento de Estado a duvidar da sinceridade brasileira. Em carta de desculpas ao General Mathew Ridgway, Comandante das Forças da ONU na Coréia, Miller, antes otimista, explicou que Goés passava a maior parte do tempo "repetindo as já conhecidas reclamações contra os Estados Unidos". O enviado brasileiro ficou em Washington três meses e a única concessão que fez foi acenar com a possibilidade de um entendimento sobre a preparação de uma força expedicionária, mas o Governo brasileiro nem sequer se deu ao trabalho de responder ao projeto de acordo apresenta- do nesse sentido. Este episódio pôs fim a quaisquer entendimentos bilaterais sérios sobre a participação militar brasileira na Coréia. Segundo comentou Miller, amargamente, alguns dias após a partida do General, "Goés tinha sido a 'oferenda' (imolada) em lugar da defunta missão à Coréia" 45 .

Ao iniciar-se o último ano do mandato de Truman, o duradouro relacionamento especial sofrera dramática erosão. Uma força expedicionária brasileira era agora assunto encerrado. Embora o governo brasileiro concordasse em negociar um pacto de assistência militar, no quadro da nova lei de segurança recíproca americana, se comprometeu a um programa trienal de compras de produtos considerados essenciais. Além disso, João Neves se apressou em assegurar ao Presidente Getúlio Vargas que a tese brasileira de atribuir dimensão econômica às relações militares fora vigorosamente susientada e que o país não assumira qualquer obrigação político-militar adicional ${ }^{46}$. Mesmo assim, este pacto provocou tamanha oposição no Congresso brasileiro que, à medida em que avançava o ano, sua ratificação parecia cada vez mais duvidosa.

O entusiasmo de ambas as partes pela Comissão Mista se dissipava. Descrita, corretamente, por Miller, como instrumento crucial da política com o Brasil, a Comissão fora constituída em julho de 1951 e começara imediatamente a trabalhar na definição de programas de investimento. Uma viagem do Ministro da Fazenda brasileiro a Washington, em setembro, produziu manifestaçðes tranqüilizadoras do BIRD e do Banco de Exportação e Importação. Era com essa ajuda oficial, ou semi-oficial e não com capital estrangeiro privado, que o Brasil contava. $\mathrm{Na}$ medida em que se reacendiam as esperanças de obter esse tipo de ajuda, crescia a oposição ao outro tipo, especialmente tendo em vista as graves dificuldades da balança de pagamentos do Brasil. Pressionado por grupos nacionalistas, crescentemente vocais, Getúlio Vargas propôs ao Congresso a criação de uma empresa estatal de petróleo (Petrobrás) e a limitação da participação estrangeira na indústria de petróleo. Em janeiro de 1952, Getúlio impôs um teto de $10 \%$ à remessa de lucros ${ }^{47}$. Desconfiados, o Banco de Exportação e Importação e o BIRD passarama encarar com menor tolerância as dificuldades financeiras do Brasil, revelando relutância maior em conceder-lhe novos empréstimos. Segundo Marwin Bohan, chefe da seção americana da Comissão Mista Brasil-Estados Unidos, o resultado foi que, em meados de 1952, o Governo de Getúlio Vargas tinha "perdido toda a confiança na Comissão"48. Preocupação com a enfraquecida aliança teria sido o motivo da decisão de Acheson e Miller de visitar o Brasil em julho, mas nada de concreto resultou da viagem e o ceticismo brasileiro aumentou. De fato, ao longo de todo o ano, governantes brasileiros lamentaram 
o "abandono" de Washington e advertiram que o desenvolvimento brasileiro era a chave para a defesa da América Latina ${ }^{49}$.

Com a vitória eleitoral de Eisenhower em novembro a sorte da antiga aliança caía em mãos republicanas. Jõao Neves visitou Washington naquela mês e saiu com uma impressão positiva dos encontros com o Presidente eleito, com o futuro Secretário de Estado, John Foster Dulles e com o futuro assessor presidencial, Nelson Rockefeller. Eisenhower frisou a necessidade de união contra os soviéticos e tanto ele quanto Rockefeller prometeram ajuda. Estas eram boas novas pois o déficit da balança de pagamentos mais que duplicara naquele ano e as reservas de divisas haviam chegado ao seu mais baixo nível desde a guerra ${ }^{50}$.

Mais uma vez a desilução não tardou a chegar. Em fins de 1952, o Departamento de Estado se comprometeu a obter para o Brasil empréstimo de US\$ 300 milhões para eliminção de atrasados comerciais desde que o governo de Getúlio Vargas criasse um mercado livre de câmbio que facilitasse a remessa de lucros. Em fevereiro de 1953, o Brasil cumpria sua parte do compromisso mas quando procurou Washington sobre o empréstimo, a administração Eisenhower refugou. O Secretário do Tesouro George Humphrey, queixando-se da "confusão que herdara", se mostrou particularmente insistente em reduzir o montante a um terço. A Agência Central de Inteligência (CIA) alertou para o fato de que, dando ao Brasil os US\$ 300 milhões, Washington perderia o poder de pressão política quanto a outras questões, e o Presidente Eisenhower foi convencido de que o empréstimo poderia ser reduzido, no mínimo, à metade ${ }^{51}$. Quando o substituto de Marício Nabuco visitou Dulles para adverti-lo de que as relaçðes entre os dois países haviam caído a nível "perigoso"e institir em que os aspectos políticos do empréstimo fossem tomados em conta, Dulles declarou que Washington achava que US\$100 milhões seriam suficientes. Getúlio Vargas ficou tão agastado que determinou a suspensão das negociações e Miller lembrou a Dulles que a Argentina recebera ajuda semelhante e que as relações como Brasil haviam chegado a um "ponto crítico". Humphrey depois de vários dias, do que Eisenhower chamou de "acalorado debate", acabou admitindo que a administração estava comprometida ("fisgada"). Certamente não foi coincidência o fato de que, uma semana depois da assinatura formal do contrato de empréstimo, o Congresso brasileiro, finalmente, ratificou o pacto militar, deixando o Embaixador Johnson com a esperança de que "nenhum prejuízo concreto tivesse resultado do inesperado atraso"

O fato de que o empréstimo só fora obtido após intensa pressão diplomática, reforçou as já en- tão generalizadas dúvidas dos meios dirigentes brasileiros quanto ao relacionamento especial, ainda mais enfraquecido pelo interesse decrescente de Washington em relação à Comissão Mista. Em janeiro de 1953, a Comissão havia definido um "programa de mais de um bilhão de dólares", $60 \%$ do qual a ser financiado com recursos orçamentários brasileiros mas só conseguiria US\$ 119 milhões de dólares do Banco de Exportação e Importação e do BIRD. Bohan advertiu o Departamento de Estado de que a Comissão Mista "não era um empreendimento essencialmente econômico mas sim um programa político bilateral de primordial importância". Mas a nova administração, decididamente, não estava interessada em financiar com recursos públicos (oficiais) o desenvolvimento brasileiro, sobretudo agora que o conflito coreano esmorecia. Em fevereiro, Humphrey se referiu à falta de "espinha dorsal" do Banco de Exportação e Importação em anos anteriores e Dulles insistiu com o Presidente para que deixasse claro ao Brasil que o capital privado estrangeiro era a solução correta para seus problemas. Durante conversa que teve, em março com o Ministro da Guerra brasileiro, Eisenhower foi propositadamente vago quanto ao tema de auxílio econômico. Nesse mesmo mês, Washington propôs a extinção da Comissão Mista e, em abril, anunciou que o irmão do Presidente, Milton Eisenhower, visitaria vários países sul americanos, inclusive o Brasil, para discutir a política norte-amercana ${ }^{53}$.

Getúlio Vargas queria evitar a dissolução da Comissão Mista antes de ser obtido auxílio financeiro, pelo menos, até o limite dos US\$ 300 milhões prometidos pela administração Truman. João Neves pressionou o Embaixador Johnson sobre esse aspecto, em abril, e Getúlio enviou seus hábeis filha e genro aos Estados Unidos para conversar com autoridades republicanas, as quais negaram qualquer compromisso de financiar projetos da Comissão Mista até determinados níveis. Em maio, Eugene Black, Presidente do BIRD, chegou mesmo a prevenir as autoridades brasileiras contra "novo ciclo de esperanças excessivas" no tocante a auxílio financeiro, uma vez extinta a Comissãó Mista. O anúncio, em julho, de que Washington de fato resolvera dissolver a Comissão Mista provocou uma explosão de ressentimento no Brasil. João Neves qualificou a decisão como uma "bofetada", enquanto a imprensa condenava Washington pelo não cumprimento do que os brasileiros entendiam como compromissos firmemente assumidos ${ }^{54}$.

"Os brasileiros estavam furiosos e não se preocupavam em ocultar sua ira", descobriu Milton Eisenhower ao chegar, em julho. A carta que trazia da Casa Branca para Getúlio falava do desejo de fortalecimento de relações, mas -Eisenhower naturalmente pensava em termos de investimentos priva- 
dos. Ele recentemente comentara, durante uma reunião com seu ministério, que capital privado e auto-ajuda eram o de que precisava a América Latina e era esse o evangelho que seu irmão pretendia pregar no Brasil. "O tipo de assistência técnica que vocês receberam vale tanto quanto dinheiro", declarou Milton Eisenhower a autoridades brasileiras, as quais não conseguiam acreditar no que ouviam. A resposta de Getúlio Vargas à carta de Eisenhower se contituiu em polida reprimenda na qual encarecia uma "rápida e abrangente" solução para os problemas bilaterais. Mas não havia esperança de se obter auxílio do tipo e no grau desejados pelos dirigentes brasileiros. De volta aos Estados Unidos, Milton Eisenhower deu conhecimento ao irmão do ressentimento brasileiro, e o advertiu de que a cooperação brasileira era "vital". Ao mesmo tempo, preveniu-o contra "singularizar o Brasil" nas relações dos Estados Unidos com a América Latina. Após a leitura de um longo relatório em que Milton Eisenhower valorizava a auto-suficiência e a iniciativa privada, o Presidente Eisenhower afirmou que o documento "deveria ser estudado por cada homem, mulher e criança em toda a América do Norte e do Sul". O relatório, após cortes determinados pelo Presidente Eisenhower para "poupar a sensibilidade de nossos amigos sul-americanos", foi publicado. A reação da Embaixada brasileira foi de desapontamento. O documento "superficial" era apenas uma tentativa de "racionalização" do abandono da América Latina por Washington, lamentava o Embaixador João Carlos Muniz, em correspondência particular ao Ministro da Fazenda, Oswaldo Aranha. Poderia, em sua opinião, ter sido escrito sem que fosse necessária uma viagem à região. "No momento em que a propaganda comunista acena com a possibilidade de industrialização intensiva e rápida para as áreas subdesenvolvidas, a missão Eisenhower promete apenas o instrumento antiquado, não mais aplicável às condições atuais, das inversões privadas" 55 .

O fim da guerra da Coréia reduziu ainda mais o poder de negociação do Brasil, reforçando a insistência de Washington em favor dos investimentos privados estrangeiros como chave para o desenvolvimento da América Latina e fortalecendo a preferência americana pelas iniciativas políticas como meio adequado para enfrentar o desafio comunista no hemisfério. Como reconheceu Dulles, em principios de 1954, durante uma reunião ministerial que tratava da próxima conferência interamericana de Caracas, os governos latino-americanos queriam discutir a cooperação econômica, mas o ponto crucial era assegurar medidas anticomunistas imediatas, "em vez de esperar que se crie uma situação semelhante à da China em fins da década de 40 , quando o auxílio americano chegou tarde demais" 56 .

Washington continuava a fazer pequenos gestos de apoio a um entendimento especial com o Brasil mas se recusava a conceder o tipo de auxilio ao desenvolvimento-maciço e de longo prazo e a assistência militar preferencial que os dirigentes brasileiros desejavam. Em 1954, depois que o Congresso brasileiro aprovou legislação sobre o petróleo mais nacionalista ainda do que a própria proposta Getúlio Vargas, o Brasil conseguiu menos de US\$ 3 milhões do Banco de Exportaç̃̃es e Importação ${ }^{57}$. O clamor contra o descaso americano pelo relacionamento especial se tornou estridente. Editorialistas, comentaristas internacionais, planejadores econômicos, porta-vozes militares, diplomatas e autoridades governamentais - todos formaram um coro de protesto e ressentimento. Em fins de 1953 surgiram notícias na imprensa de que o Itamaraty pretendia reorientar a política externa do país numa direcão neutralista. Embora o Ministro do Exterior desmentisse para a Embaixada americana o noticiário, esta registrou, com certa preocupação, que o novo Chefe de Gabinete era um "partidário declarado de mudanças na política externa... que achava que o Brasil devia perseguir uma política, não necessariamente oposta mas paralela à dos Estados Unidos e dela diversa"

A recusa brasileira em contribuir com tropas para o esforço da ONU na Coréia fora indício dramático de que algo acontecera àquele relacionamento. Menos dramático na forma mas de conseqüências de maior alcance foi outro sinal: a vigorosa campanha brasileira visando ampliar suas opções econômicas internacionais. Em parte, o interesse por outros mercados advinha do aspecto financeiro, mas o descontentamento generalizado em relação à parceria americana agiu como importante estímulo no esforço para alcançar maior autonomia.

Em março de 1952, por exemplo, João Neves assinalou crescimento do interesse europeu pelo Brasil e instou Getúlio Vargas a buscar "um máximo de diversificação" de mercados e fornecedores, especialmente tendo em vista as dificuldades no relacionamento com Washington. Constatando o extraordinário progresso alcançado durante os dois anos subseqüentes, no comércio e nas relações de investimentos com a Alemanha Ocidental, o sucessor de João Neves comentou que o estímulo ao capital europeu era necessário já que o auxilio ao desenvolvimento proveniente de outras fontes se havia revelado "claramente inadequado" 59.

De particular significação foram os sintomas de uma incipiente reavaliação da atitude do Brasil em relação à América Latina. Tentativas de intensificação de relações com paises vizinhos, especialmente a Bolívia e o Paraguai, faziam parte de uma estratégia tradicional visando a contrabalançar a influência argentina ${ }^{60}$, mas surgiam claros índices de que os planejadores brasileiros, em sua insatisfação 
com Washington, começaram a questionar os efeitos do duvidoso relacionamento especial sobre a posição brasileira na América do Sul61. A Conferência de Washington foi, é claro, excepcional, na medida em que o Brasil se alinhou publicamente com outros países latino-americanos contra os Estados Unidos. A reação encorajadora das delegações hispanoamericanas pode ter reforçado as dúvidas brasileiras. Estímulo mais importante, no entanto, foi a constatação de que por toda a América Latina a lista de reclamações contra os Estados Unidos crescia rapidamente e que uma certa dose de suspeita e animosidade se transferia para o Brasil à raiz de sua solidariedade histórica com Washington 63 .

O governo-tampão do Vice-Presidente Café Filho (1954-55), que assumiu a Presidência quando Getúlio Vargas se suicidou em 1954, não trouxe mudança nas relações do Brasil com os Estados Unidos. Pouco depois de assumir, Café Filho enviou seu Ministro da Fazenda a Washington para tratar do que qualificou para o Presidente Eisenhower como sendo problemas "de fundamental importância para nossas futuras relações". O Presidente americano se manifestou "profundamente simpático" às aspirações brasileiras ${ }^{64}$, mas os entendimentos não resultaram em solução alguma para a divergência política básica. No Departamento do Tesouro existia pouca simpatia pela posição brasileira. O Secretário Humphrey, partidário de mal-definida atitude "dura e contundente" em relação à América Latina, comentava em particular, nessa época, que estava "totalmente convencido de que uma política branda e de conquista da América Latina mediante dispêndio de recursos não era o caminho certo". Mais especificamente, criticou as pretensões brasileiras de produzir, com auxílio do Banco de Exportação e lmportação, folhas-de-flandres, de modo a reduzir sua dependência em relação a duas empresas americanas. Enquanto o Ministro da Guerra de Café Filho se queixava amargamente do abandono americano, do auxílio dado pelos Estados Unidos a outras regiões subdesenvolvidas e das pressões americanas contra a Petrobrás e outras manifestaç̃es estatizantes no Brasil, Eisenhower dizia que os Estados Unidos "seriam amigos compreensivos e solícitos mas que nossos compromissos globais eram pesados" $^{\prime \prime}$. Durante reunião ministerial em dezembro, o presidente americano, aludindo às reclamações latino-americanas, justificou o auxílio preferencial dado à Ásia com o argumento de que os Estados Unidos também estavam defendendo interesses da América Latina no Extremo Oriente ${ }^{65}$.

O velho estadista Raul Fernandes, novamente à frente do Itamarati, fez seu último apelo em favor de um relacionamento especial em janeiro de 1955. Em carta a Muniz, destinada a Rockefeller, Raul Fer- nandes reclamou que Washington não dissociava o Brasil do resto da América Latina e tratava os pedidos brasileiros de auxílio como "operações bancárias" e não como matéria política e de segurança. Lembrava que haviam sido colocados recursos à disposição da Europa e que a razão dominante não fora vantagem financeira mas sim a segurança do Ocidente. Rockefeller encaminhou a carta a Dulles e, às pressas, marcou-se uma reunião de Muniz com funcionários do Departamento de Estado, cujo resultado, no entanto, foi um sermão sobre a necessidade de orçamentos equilibrados, de inflação controlada e de liberalização da legislação sobre petróleo, de modo a permitir a participação de capital estrangeiro. O secretário-adjunto Henry Holland, segundo memorandum do Departamento de Estado sobre a reunião, disse a Muniz que aquelas "eram todas questões que só o Brasil podia resolver e que de sua solução dependia qualquer progresso econômico permanente (i.é., auxílio americano)". Semanas depois, Muniz falou no National War College (Escola Superior de Guerra) e polidamente mencionou o acúmulo de aspirações insatisfeitas. O Ponto 4, afirmou, fora um "brando paliativo", comparado com o Plano Marshall, enquanto que a Comissão Mista Brasil-Estados resulta num "anticlimax". Washington devia lembrar-se das contribuições brasileiras durante a II Guerra Mundial e precisava entender que o desenvolvimento econômico era a melhor defesa contra o comunismo ${ }^{66}$. Ao encerrarse o breve governo de Café Filho o abandono americano era o tema dominante nos comentários brasileiros sobre as relações com os Estados Unidos ${ }^{67}$.

Ao considerarem a vitória eleitoral de Juscelino Kubitschek de Oliveira e de seu esquerdizante companheiro de chapa João Goulart, o que mais parecia preocupar os dirigentes republicanos era a atividade comunista no Brasil. Para aferir a atitude de Juscelino Kubitschek, o Departamento de Estado o convidou a visitar Washington antes de sua posse. 0 Vice-Presidente Nixon expressou o interesse da administração: era importante fazer "todo o possível para começar com o pé direito o relacionamento com o novo governo brasileiro e dar a Juscelino a oportunidade de se comprometer com um programa anticomunista" 68 . Os dirigentes brasileiros também se preocupavam com as tramas comunistas, mas discordavam da solução. O que os deixava profundamente intrigados era o recurso de Washington ao auxílio econômico para enfrentar o desafio na Europa e na Ásia ao mesmo tempo em que insistia em métodos político-policiais para a América Latina ${ }^{69}$. O desentendimento aflorou mais uma vez, durante a visita de Juscelino, em janeiro de 1956. Dulles e seus assessores discorreram exaustivamente sobre as necessidades de um grande esforço anticomunista e ofereceram assistência técnica para esse fim, en- 
quanto Juscelino pretendeu discutir o financiamento de seu plano qüinqüenal de desenvolvimento. Embora se dizendo dispostas a "ouvir" as propostas brasileiras, as autoridades americanas advertiram Juscelino de que quaisquer projetos concretos deviam fazer parte de um "pacote" de recuperação econômica ${ }^{70}$. O Brasil deveria colocar suas finanças em ordem, liberalizando a legislação sobre investimentos e eliminando os déficits orçamentários. Contatos e discussões subseqüentes apenas confirmaram o conflito de políticas. Nixon foi ao Brasil e retomou o tema da cruzada anticomunista. Juscelino concordou e disse que o Brasil precisava de US\$ 1,2 bilhões em investimentos de capital para estimular o desenvolvimento necessário à contenção do radicalismo. Nixon replicou que auxílio econômico dependia do Congresso e que este era influenciado pela estabilidade financeira e política do país-cliente e pela atitude deste em relação ao comunismo. Em discurso público, Juscelino recordou a Nixon que "a liberdade é apenas uma palavra para os que vivem na extrema pobreza" e este foi o recado que mandou a Washington por intermédio de seu VicePresidente poucas semanas depois. Em carta a Eisenhower, entregue por João Goulart, Juscelino insistia em que "um consistente esforço governamental - auxílio oficial americano - era necessário em setores da infra-estrutura pouco atraentes para os investidores privados. Os apelos brasileiros continuavam, no entanto, a encontrar poucas receptividade em Washington. Dulles comunicou a Eisenhower que havia adotado uma atitude de espera, "sujeita a maiores esclarecimentos", quanto à orientação de Juscelino; dai nenhum compromisso ter sido assumido com João Goulart, além da promessa de exame de pedidos de empréstimos. Eisenhower em sua resposta a Juscelino ignorou cuidadosamente a menção de seu interlocutor a auxílio oficial, ressaltando, ao invés, a necessidade de que fosse feito "todo o possivel para tranqüilizar a iniciativa privada quanto ao grande potencial brasileiro" "71. A esta altura, mesmo os mais inflamados defensores brasileiros do relacionamento especial se viam levados a admitir, em discussões privadas, a futilidade básica dessa estratégia ${ }^{72}$

No campo militar as expectativas brasileiras não tiveram melhor sorte. Estrategistas militares no Brasil estavam preocupados com a capacidade de sua defesa costeira e queriam organizar um grupo anti-submarino de caça e destruição, do qual fariam parte um porta-aviões, destróires e aviões. Em maio de 1954, haviam solicitado a cessão de quatro submarinos e navios de escolta, mas quase dois anos se passaram antes que Washington concordasse em "emprestar" dois velhos submarinos. Em marco de 1956, o Brasil manifestou o desejo de comprar um porta-aviões, mas o Pentágono foi contrário à venda diante das repercussões desfavoráveis para as relações dos Estados Unidos com a Argentina. Esta decisão levou o Brasil a comprar um porta-aviões da Grã-Bretanha. Um ano depois, o pedido dos Estados Unidos de autorização para instalar uma estação de rastreamento de mísseis na ilha de Fernando de Noronha parecia criar nova oportunidade e o Brasil, de início, insistiu em um quid pro quo sob a forma de armamento pesado adicional. A "mágoa" dos círculos militares ante a mesquinhez de Washington no tocante à cessão de armamentos, advertiu o Embaixador Briggs, era fator de suma importância na reação "incrivelmente confusa e frustante" do Brasil à pretensão americana ${ }^{73}$. Washington, no entanto, se recusou a negociar nas bases propostas, apelando, ao invés, para o sentimento de dever do Brasil para com a defesa do ocidente. Juscelino recuou, apesar da ruidosa oposição da esquerda brasileira, mas insistiu na inclusão no acordo, assinado em Janeiro de 1957, de uma cláusula que implicitamente comprometia os Estados Unidos a uma maior ajuda. O Itamarati levou adiante a questão, reclamando do Departamento de Estado que, até aquela data, tudo o que os Estados Unidos haviam feito, nos termos do pacto de assistência militar de 1952, fora ajudar a conservar um "núcleo de navios antiquados e sem valor". Em fevereiro, Juscelino enviou um lembrete pessoal a Eisenhower. As conversaçõesno entanto, se arrastavam e no fim do ano, o Embaixador Briggs, inquieto ante a tendência das relações americano-brasileiras e que já advertira o Departamento de Estado de que o Brasil merecia um "lugar especial" na política dos Estados Unidos na América Latina, criticou seus superiores pelo fato de que os brasileiros "poucos resultados visíveis" estavam obtendo nas negociações sobre armamentos. Em fins de 1958, a Embaixada do Brasil em Washington ainda estaria reclamando que as necessidades brasileiras não tinham sido atendidas ${ }^{74}$

Em 1958, as relaç̃es americano-brasileiras tinham, aos tropeços, chegado a uma encruzilhada que não era claramente percebida em Washington. As autoridades brasileiras haviam continuado a criticar acerbamente o aparente desinteresse americano pelo relacionamento especial e começavam a propor um novo realismo no trato com os Estados Unidos $^{75}$. Até a imprensa conservadora, que por muito tempo advogara a aliança, agora, expressava seu desencanto ${ }^{76}$. Do lado americano, Briggs, transformado em defensor de um tratamento preferencial para o Brasil, alertava, em fins de 1957, para a possibilidade "de alguma reorientação da diplomacia brasileira numa direção neutralista". . No entanto, sua opinião sobre o governo de Juscelino Kubitschek era essencialmente negativa e no Departamento de Estado parecia existir a tendência de atribuir as lamentações brasileiras aos métodos administrati- 
vos desleixados, às quer elas interpartidárias e ao "clima psicológico adverso resultante do ultranacionalismo de inspiração comunista" do governo Juscelino. A malfadada viagem de Nixon à América do Sul, naquele ano, gerou dúvidas quanto a essas interpretações, mas o próprio Vice-Presidente, ao regressar da viagem, relatou ao Gabinete americano que considerava "a crítica política aos Estados Unidos por abrigar ditadores foragidos mais importantes do que as diversas reclamações de caráter econômico". Talvez o próprio Eisenhower tampouco se tenha apercebido do ponto a que chegara a ânsia por auxílio maciço para o desenvolvimento, tanto no Brasil quanto nos outros países da América Latina. A região tinha graves problemas econômicos, concordava ele, em conversa com um diplomata, na época, mas havia uma "falta de compreensão da parte da América Latina quanto ao grau de auxílio que Washington já lhe estava concedendo"77.

De importância fundamental para as futuras relações era a crescente certeza dos círculos dirigentes brasileiros de que a estratégia nacional em relação aos Estados Unidos e à América espanhola se revelara contraproducente e que a única forma de o Brasil adquirir o indispensável poder de barganha vis-a-vis Washington seria aliar-se aos vizinhos hispânicos. Durante seus primeiros dois anos de governo, Juscelino afirmara, repetidamente, seu desejo de maior cooperação com a América espanhola e desencadeara vigorosa ofensiva diplomática nos países limítrofes. O Itamarati concluíra uma variedade de acordos culturais, econômicos e de comunicações. Estes êxitos reforçavam as dúvidas sobre a sabedoria de uma política histórica de semiisolamento da América espanhola. Em fins de 1957, jornais influentes, como O Estado de São Paulo, começaram a endossar a idéia de uma 'união latinoamericana' encabeçada pelo Brasil e na Escola Superior de Guerra, analistas se referiam ao fracasso do relacionamento especial e apontavam esta união como uma alternativa promissora ${ }^{78}$. 0 Embaixador Briggs nunca se afastou tanto da realidade como quando desprezou como "embromação" a crescente ênfase brasileira numa comunidade de interesse com a América espanhola. Esse tipo de conversa era "ótimo para discursos de fim de banquete e tratativas da ONU com os árabes" escrevia ele, em tom de menosprezo, "mas carece de maior substância". Uma palestra confidencial proferida na Escola Superior de Guerra, em maior de 1958, pelo Chefe da Divisão Política do Itamarati, evidenciou o quanto se equivocava o enviado americano. Disse o conferencista que a integração latino-americana iria ocorrer com ou sem o Brasil, pelo que o Brasil devia liderar o movimento e desse modo colocar-se em posição de "negociar mais efetivamente" com os Estados Unidos"7.
Essa conclusão, aparentemente, já predominava nos meios formuladores de política do Brasil em meados de 1958, quando a triste experiência de Nixon na América do Sul ofereceu a Juscelino dramática oportunidade para lançar a nova estratégia. O primeiro passo do que ficou conhecido como a Operação Panamericana (OPA) foi uma carta a Eisenhower, em 28 de maio, pedindo uma mudança na política americana em relação à América Latina como um todo. Significativamente, foi o Embaixador Augusto Frederico Schmidt, crítico contumaz dos Estados Unidos, quem colaborou com Juscelino na redação da carta ${ }^{80}$. Em seguida, Juscelino usou o rádio para mobilizar apoio doméstico para sua iniciativa, instruiu o Itamarati no sentido de buscar solidariedade junto às missões diplomáticas hispanoamericanas e comecou a corresponder-se com chefes de governo vizinhos ${ }^{81}$. A reação pouco entusiástica de Washington à iniciativa brasileira sugere que seu significado, em termos de relações brasileiroamericanas, passou desapercebido no Departamento de Estado, o qual tampouco avaliou suficientemente a desilusão que motivava a atitude do Brasil. Dulles sugeriu ao Presidente Eisenhower que 0 Secretário de Estado-adjunto, Roy Rubottom, levasse uma resposta interlocutória a Juscelino, com o que melhor poderia identificar as intenç̃es do governo brasileiro; Eisenhower concordou. A carta dirigida a Juscelino apoiava "medidas corretivas" visando reforçar a solidariedade continental, mas, refletindo a preocupação primordial de Washington, ressaltava, especificamente, a necessidade de "maior implementação" da resolução anti-comunista aprovada na conferência de Caracas de 1954. O encontro de Rubotton com Juscelino, em junho, revelou a mesma divergência de énfase. Juscelino atribuiu o descontentamento latino-americano e a simpatia pelo comunismo à miséria social resultante do atraso econômico, enquanto Rubotton, por seu lado, considerou o desafio comunista como sendo uma questão essencialmente policial. Um memorandum posteriormente entregue por Briggs ao Itamarati reconhecia, pro-forma, o desenvolvimento econômico como meio de conter extremismos mas advertia que os governos latino-americanos deviam, "com maior energia", combater, por outras formas, as "forças externas" que estavam subvertendo a solidariedade continental. Esse foi exatamente o tipo de argumento que Dulles utilizou quando visitou 0 Brasil em julho daquele ano. "Havia uma nítida linha divisoria", lembrava Juscelino nas sucessivas conversas com Dulles, "entre o que pretendia o Brasil e a doutrina exposta pelos Estados Unidos. Dulles, "um argumentador tenaz, intransigente, quase incapaz de aceitar um compromisso", insistia em orientar a conversa para a ameaça comunista e chegou até a propor um acordo bilateral anticomunista, ao passo que Juscelino insistia na conhecida tese do 
desenvolvimento econômico como caminho para a segurança hemisférica ${ }^{82}$.

Briggs diria em princípios de 1959: "evitar que nossos inimigos poluam o reservatório da tradicional boa-vontade brasileira deve continuar a ser princípio básico da política dos Estados Unidos". Ao mesmo tempo achava que os Estados Unidos faziam, para a América Latina, o papel de "bode expiatório domesticado" e que Washington deveria avaliar os pedidos de auxílio econômico do Brasil de acordo com os esforços brasileiros de manter clima favorável aos investimentos privados". Washington acabou concordando com a criação do Banco Interamericano de Desenvolvimento, mas discordou radicalmente do governo de Juscelino quanto ao montante de capitalização ${ }^{83}$. A reticência americana estimulou Juscelino, Schmidt e outras autoridades brasileiras a manterem vivas as teses de abandono americano e da unidade latino-americana, o que dava razão ao sucessor de Briggs, John Moors Cabot, quando chamou a atenção de Washington para o sentimento brasileiro de que o país não estava recebendo dos Estados Unidos auxílio "compatível com o que precisava e lhe era devido" 84

O ressentimento brasileiro cresceu ao constatar que o verdadeiro motivo do maior interesse de Washington pela América Latina se originava na renovada ameaça comunista, sob a forma da Cuba de Fidel Castro. Não foi outro o motivo da visita de Eisenhower à região em 1960. Antes que Eisenhower embarcasse para a América Latina, Juscelino insistiu com ele para que se pronunciasse em favor do desenvolvimento econômico como chave para a democracia - o que no entender de Juscelino significava, é claro, maior assistência governamental. Mais uma vez, no entanto, Eisenhower encareceu a suas platéias latino-americanas a sabedoria do recurso ao capital privado estrangeiro. Surpreso ante a relutância de Juscelino e de seus colegas hispanoamericanos em adotar uma postura anticastrista, Eisenhower, de regresso a Washington, advertiu o novo Chanceler brasileiro de que "o problema cubano afetava todas as Américas e não era, apenas, um problema dos Estados Unidos", Juscelino recordou a Eisenhower em julho, em particular, aquilo que lhe parecia o verdadeiro desafio. Sublinhando a necessidade de um novo programa de "financiamento público" Juscelino voltou a queixar-se do abandono americano e advertiu para o fato de que a segurança do Ocidente se achava ameaçada pelo atraso econômico na América Latina ${ }^{85}$. Ao final de seu mandato, Juscelino estava convencido de que o Departamento de Estado sabotara a OPA ${ }^{86}$.

$O$ verdadeiro significado da OPA não parece ter sido bem compreendido em Washington. No fim dos anos 60, o Embaixador americano no Rio de Janeiro, inquieto mas aparentemente incerto sobre o que acontecera, manifestava o temor de que, se o Brasil optasse por liderar um bloco independente de estados latino-americanos "isso poderia significar o começo do colapso do sistema interamericano". Ele também achava que as relaç̃es americanobrasileiras "chegaram ou, em breve, chegarão a uma encruzilhada"87. Embora tardia, essa avaliação estava correta na medida em que o sistema linteramericano) presumia um relacionamento especial entre Brasil e Estados Unidos. Os desencantados dirigentes brasileiros se davam perfeita conta do que acontecera. Muniz, em artigo publicado em fins de 1959, explicava que a procura do entendimento bilateral com os "grandes núcleos industrializados" havia resultado infrutífera; por isso o Brasil optara por uma frente negociadora de amplitudie continental. Para outro diplomata, em palestra reservada, na E.S.G. no ano seguinte, a OPA tinha sido "a primeira atitude inteiramente independente do Brasil" em relação aos Estados Unidos. Foi o Embaixador Henrique Rodrigues Valle, em palestra semelhante, quem melhor definiu o que acontecera. A iniciativa de Juscelino representara "uma reviravolta quase completa" na política exterior do Brasil. "Mais do que isso", prosseguiu, " (O Brasil) passa a desempenhar papel avesso ao que até então se acostumarae, de intérprete dos Estados Unidos junto à América Latina, se transforma em advogado dos latinoamericanos frente à potência do Norte" 88 .

Visto à luz das experiência brasileiras com o relacionamento especial nos anos 50 , o período que se seguiu de Quadros - Goulart (1961-64), durante o qual os dirigentes brasileiros estusiasticamente lançaram sua "política exterior independente" e ruidosamente proclamaram a solidariedade com o Terceiro Mundo ${ }^{89}$, não passou de uma execução exagerada da nova estratégia de Juscelino Kubitschek. Na verdade, o empenho com que todos os governos pós-Juscelino, mesmo os regimes militares ativamente anticomunistas dos fins dos anos 60 e da década de 70, perseguiram uma intensificação das relações com a América espanhola e, uma vez alcançado, grau significativo de industrialização e suficientemente diversificada a dependência externa demonstraram crescente autonomia política em relação a Washington, sugere que as variações políticas introduzidas após a revolução de 1964 não passavam de meras manobras táticas destinadas a tranqüilizar fontes externas de empréstimos e investimentos com vistas a reativar a engrenagem econômicas nacional, semiparalisada pelas políticas inflacionárias de Juscelino, Jânio e João Goulart.

Apesar disso, parece claro que o impacto negativo dos primeiros quinze anos da Guerra Fria sobre as relações americano-brasileiras foi decisivo pa- 
ra o curso subseqüente desse relacionamento. Foi durante aquele período, marcado pela crise coreana, que a tese do abandono americano se tornou elemento preponderante no pensamento da elite brasileira formuladora de política externa. Ao final daquele conflito a convicção de que Washington não estava interessado num verdadeiro relacionamento especial com o Brasil, exceto em situações de emergência internacional, quando conviesse aos objetivos americanos, se disseminou pelos círculos decisórios brasileiros, gerando dúvidas crescentes quanto à sabedoria ou mesmo a conveniência de persistir na tentativa de forjar tal relacionamento. A subseqüente reviravolta da estratégia do Brasil em relação aos Estados Unidos e à América Espanhola - da qual a primeira manifestação foi a OPA de Juscelino Kubitschek - foi a conseqüência dessa desilusão.

Todas as administrações do pós-guerra, democratas e republicanas, têm responsabilidade por essa mudança. Os dirigentes americanos davam prioridade aos problemas europeuse asiáticose tendiam a só prestar atenção aos países latinoamericanos quando estes ämeaçavam o equilíbrio hemisférico ou se tornavam alvos da conspiração comunista. Não existiam poderosos interesses burocráticos ou institucionais advogando a causa do relacionamento especial com o Brasil e, temerosos de incorrer em maior animosidade hispanoamericana pelo claro favorecimento do gigante sulamericano, os porta-vozes da administração dos Estados Unidos optaram por resistir aos apelos brasileiros por uma assistência preferencial e maciça. Com sua relutância em adotar uma eficaz política de 'país-chave' em relação à América Latina, Washington alienou o Brasil, antes um entusiástico aliado em questões hemisféricas. Também contribuiu consideravelmente para o declínio, a longo prazo, da influência americana na região, ao impelir o Brasil pelo caminho da solidariedade com seus antagonistas históricos, os hispano-americanos.

\section{Notas}

1. GALL, Norman. Atoms for Brazil, dangers for all. Foreign Policy, 23: 155-201, Verão, 1976. FONTAINE, Roger W. The end of a beautiful relationship. Foreign Policy. 28: 166-74, outono, 1977. FISHLOW, Albert. Flying down to Rio; perspectives on U.S.A. Brasilian relations. Foreign Affairs, 57:387-405, inverno, 1978/9.

2. BURNS, E. Bradford. The Unwritten alliance: Rio-Branco and Brazilian American relations. Nova lorque, 1966. HILTON, Stanley E... Brazil and the Post-Versailles world; elite images and foreign policy strategy, 1919-1929. Journal of Latin-American Alliance, 1937 - 1945, Princeton, 1973.

3. HILTON, Stanley E.. Brasilian diplomacy and the Washington-Rio de Janeiro axis during the World War II Era. Hispanic American Historical Review, 59: 201-31, maio, 1979.
4. As expressర̃es de alarme eram inúmeras. Ver, por exemplo, MUNIZ, Joăo Carlos a ARANHA, Oswaldo. Arquivo Oswaldo. Centro de Pesquisa e Documentação de História Contemporânea. Fundação Getúlio Vargas. Rio de Janeiro. 26 jun. 1946. ARANHA, Oswaldo a FERNANDES, Raul. Arquivo Oswaldo Aranha. Centro de Pesquisa e Documentação de Historia Contemporânea. Fundação Getúlio Vargas. Rio de Janeiro 25 set. 1947; Arquivo Hildebrando Accioly. Rio de Janeiro. 16 nov., 1947; ACCIOLY, Hildebrando a ARANHA, Oswaldo. Arquivo Hildebrando Accioly. Rio de Janeiro, 8 out. 1947; SOUTO, Alcio a DUTRA, Eurico Gaspar. Presidência da República. Arquivo Nacional. Rio de Janeiro. 2 set. 1946. Ministro da Fazenda a DUTRA, Eurico Gaspar. Coleção Presidência da República. Arquivo Nacional. Rio de janeiro. 9 mar. 1948.

5. Quanto à preocupação brasileira nesse particular ver, por exemplo, Memorandum do Departamento de Estado dos Estados Unidos. Arquivo Geral do Departamento de Estado, 10 (caixa 28), 28 jan. 1946, Rg 59; Foreign Relations of the United States, 1946. Washington, 1969-1972, v. 11, p. 223; Correio da Manha. Rio de Janeiro, 12 maio 26 jan., 1946; Aranha e Accioly. Arquivo Oswaldo Aranha. 21 mar., 1947; Embaixada do Brasil em Buenos Aires ao Ministério das Relaçðes Exteriores. Rio de Janeiro, Arquivo Historico do /tamarati. 16 out. 1946/3 mar./17 jul. 1948. Embaixada do Brasil em Montevidéu ao Ministério das Relaçőes Exteriores. Arquivo Histórico do Itamarati. 2 mar. 1948. ACCIOLY, Hildebrando a DUTRA, Eurico Gaspar. Arquivo Histórico do /tamarati. 2 out. 1947; Ministerio da Fazenda a DUTRA, Eurico Gaspar. Coleção Presidência da República. 16 dez. 1948/13 maio 1949.

6. GONÇALVES, Roberto Mendes. Situação política no hemisfério ocidental. Arquivo Histórico do Itamarati. 23 set. 1946. ARANHA, Oswaldo a FERNANDES, Raul. Arquivo Oswaldo Aranha; 24 maio, 1947. JOHNSON, Herschel V. a JESSUP. Phillip. Arquivo Herschel V. Johnson. Independence, Biblioteca Harry S. Truman, (caixa 6) Mo. 3 set. 1948. JOHNSON, Herschel V. a VANDEBERG, Arthur. Arquivo Herschel V. Johnson. Independence, Biblioteca Harry S. Truman. 23 nov. 1949, (caixa 11); Foreign Relations of the United States, 1948. Washington, 1973-1976. v. 11 p. 26-28; RODRIGUES, Lysias A.. Geopolítica do Brasil. Rio de Janeiro, 1947. p. 138; SOUTO, Alcio a DUTRA, Eurico Gaspar. Coleção Presidência da República. 2 set. 1946; Ministro da Marinha a DUTRA, Eurico Gaspar. Colecão Presidência da República. 4 out. 1946/5 mar. 1950. Ministro da Guerra a DUTRA, Eurico Gaspar. Coleç̃o Presidência da República. 22 nov. 1950.

7. HILTON, Stanley E.. Military influence on Brazilian economic policy 1930-1945; a different view: Hispanic American Historical Review. 53: $93 \mathrm{fev}$. 1973. Estou convencido de que o futuro oferece maiores possibilidades de cooperação entre as forcas militares do Brasil e dos Estados Unidos" escreveu George C. Marshall ao Ministro da Guerra brasileira, em agosto de 1945. MARSHALL, George C. e MONTEIRO, Pedor de Goes Lexington, Instituto George C. Marshall. 13 ago. 1945, pasta 27, (caixa 34). Quanto à prioridade dada pelos governantes brasileiros à aquisição de armamento no período do apósguerra, ver TAVORA, Juarez. Uma Vida e muitas lutas: memórias. Rio de Janeiro, 1973-1976. v. 2, p. 206; Ministro da Guerra a ARANHA, Oswaldo. Arquivo Aranha. 24 fev. 1947, ACCIOLY, Hildebrando a MELO, Oswaldo Aranha de. Arquivo Accioly. 13 mar. 1947. CASTRO, Aroldo. As Crises econo micas e as Forças Armadas. Defesa Nacional, 36: 163, jan. 1949.

8. Foreign Relations of the United States, 1946. Washington, $1969 / 1972$. v. 11 , p. 90-91, 99-100, 108-110. RIDGWAY, mathew B.. Soldier: The Memoirs of Matthew B. Ridgway. Nova York, 1956. p. 173-4. Quanto ao interesse do Departamento de Estado no estímulo ao desenvolvimento de instituiç̋es democráticas na América Latina, ver Dean Rusk a Johnson, caixa 11, Arquivo Johnson. 8 set. 1949 (caixa 11). O tema geral de auxilio militar para a América Latina no apos-guerra é exami- 
nado por GREE, David, em A Contenção da América Latina. Chicago, 1971. p. 256-61, e RABE, Stephen G., Cooperação militar interamericana, 1944-1951. World Affairs. 137: 132-49, outono, 1974.

9. TRASK, Roger R. The Impact of the cold war on United States-Latin American relations, 1945-49. Diplomatic History, 1: 276-77, veråo 1977. Foreign Relations of the United States, 1947. Washington, $1972-1973$, v. 8 , p. 120

10. Memorandum do Departamento de Estado. Brazil, Escritório de Assuntos de República Americanas. Arquivo Geral do Departamento de Estado. (caixa 29), 27 ago/20 nov./4 dez. 1946; Memorandum do Departamento de Estado. Brasil, Escritorio de Assuntos de Repúblicas Americanas. Arquivo Geral do Departamento de Estado. 10 dez. 1946, maço 810.20 Defesa 12-1046.

11. ACCIOLY, Hildebrando a ARANHA Oswaldo, Arquivo Aranha. 2 abr. 1947. Correio da Manhã, 27 mar., 1947; Foreign Relations of the United States, 1948. Washington, 1975-78. v. 2, p. 549-52.

12. HILTON, Stanley E. Vargas and Brazilian economic development, 1930-1945: a reappraisal of his attitude toward industrialization, and planning. Jornal of Economic History, 35. 771-72, dez. 1975. ARANHA, Oswaldo a DUTRA. Arquivo Aranha. 11 ago. 1943.

13. DUTRA, Eurico Gaspar a TRUMAN, Harry S. Arquivo Harry S. Truman. Brazil, Biblioteca Harry S. Truman. of. 11 (caixa 47), 23 fev. 1946; TRUMAN, Harry S. a DUTRA, Eurico Gaspar. Arquivo Harry S. Truman. Brazil, Biblioteca Harry S. Truman. Brazil, Biblioteca Harry S. Truman. of. 11 (caixa 87), 23 mar. 1946; MARTINS, Carlos a Ministério das Relaç̋es Exteriores. Memorandum do Departamento de Estado. Arquivo Geral do Departamento de Estado. 6 mar. 1946, 711.32/3-646; Ministério das Relaçőes Exteriores a MARTINS. Arquivo Histórico do Itamarati. 20 mar. 1946; Aspectos of American economic and technical aid to foreign countries since mid - 1945. Departamento of State Bulletin. 16: 958, 18 maio 1947; KAPLAN, Stephen S. BONSOR, Norman C. Did United States aid really help Brazilian development? The perpective of a quater-century. Inter-American Economic Affairs. 27: 28, inverno 1973; ARANHA, Oswaldo a FERNANDES, Raul. Arquivo Aranha, 18 mar. 1947; Correio da Manhã. 27 mar. 1947. Foreign relations of the United States, 1946. Washington. v. 11, p. 493.

14. O Ministro dos Transportes brasileiro foi absolutamente claro quando advertiu funcionários americanos, em 1946, que a reação de Washington aos planos de desenvolvimento de seu governo seria tomada pelos brasileiros "sobretudo" como uma questão política. Foreign Relations of the United States, 1946. Washington. v. 11, p. 493.

15. Foreign Relations of The United States, 1947. Washington, v. 8, p. 449 - 59; NABUCO, Mauricio a DUTRA, Eurico Gaspar. Coleção Presidência da República. 29 nov. 1948. KAPLAN e BONSOR. Did United States aid really help brazilian development? 28.

16. Foreign Relations of the United States, 1946. Washington, v. 11, p. 523-4, Correio da Manhã, 25 jul. 1947; FERNAN DES, Raul a PAWLEY, Willian. Arquivo José Carlos de Mace do Soares. Rio de Janeiro, Instituto Historico Brasileiro. 1 out. 1948. Foreign Relations of the United States, 1949. Washington. v. 12, p. 552-57; ABBINK, John a TRUMAN, Harry S Brazil. Arquivo Truman (caixa 47) of. 11, 16 mar. 1949 TRUMAN, Harry S. a ABBINK, John. Brazil. Arquivo Truman. (caixa 47) of. 11, 30 mar. 1949. Para uma apreciação geral da política econômica dos Estados Unidos em relação à Ámérica Latina, no após-guerra e do debate sobre investimentos privados, ver. GREEN. Containment of Latin America. Diplomatic History. 2: 172-9/185-208/283/90 e GREEN Latin. America, 1945-1952. Diplomatic History; 2: 279-94, verão 1978.
17. Elogiando o "encaminhamento realista" da comissão quanto ao desenvolvimento brasileiro, um funcionário do Departamento de Estado se perguntava "até que ponto irá o Brasil na execução das recomendacões". CADY, John M. a JOHNSON. Arquivo Johnson. (caixa 3) 4 abr., 1949

18. Brazil Herald. Rio de Janeiro. 28 jul., 1948; SNYDER, John a MARTINS, Arquivo John Snyder. Biblioteca Harry S Truman. pasta Banco de Exportação e Importação, (caixa 12) 13 abr. 1948; SMITH, Gaddis \& ACHESON, Dean. NOVA YORK, 1972. p. 356; KAPLAN e BONSOR, Did United States aid really help Brazilian development? p. 28; Washington Post. 21 set., 1949; MILLER Jr., Edward. Discurso. 13 jan. 1950, comunicado de imprensa do Departamento de Estado, Arquivo Aranha.

19. Quanto à reação crítica no Brasil ao Plano Marshall e ao abandono do Brasil pelos Estados Unidos, ver O Jornal. Rio de Janeiro; 7 maio/4, 6, 16 jul. 1947/13 maio 1949/16 nov. 1949 Correio da Manhã, 8 set. $1948 / 25$ jan./21 out. 1949. JOHNSON ao Departamento de Estado. Arquivo Geral do Departa mento de Estado. 2 fev. 1949/março 711.32/2-249; Delegação brasileira junto às Naç̋es Unidas ao Ministério das Relaçøes Exteriores. Memorandum do Ministerio das Relaç̋es Exteriores. Arquivo Histórico do /tamarati; 31 maio, 1948.

20. Confederação Nacional da Indústria. Boletim de Informa cões. 1: 25-6/15 abr. 1948; O Jornal, 7-12 nov. 1948. Diário Carioca. Rio de Janeiro. 13 jan. 1949; Conselho Federal de Co mércio Exterior. Ata. Arquivo do Conselho Federal de Comércio Exterior. Rio de Janeiro, Arquivo Nacional. (caixa 148), 14 fev. 1949. Memorandum do Conselho Federal de Comércio Exterior. Arquivo do Conselho Federal de Comércio Exterior. (caixa 141) 11-26 ago. 1949. Diretor do Departamento Administrativo do Servico Público a DUTRA, Eurico Gaspar. Coleção Presidência da República. $18 \mathrm{abr}, 1949$. Correio da Ma nhã, 8 jun. 1949; A Noite. São Paulo, 18 set., 1949; O Estado de São Paulo. 15 set. 1949.

21. Foreign Relations of the United States, 1949. Washing ton. v. 12, 572, 574-76. Em conversa particular com Adolf A Berle, Raul Fernandes mais tarde reclamaria que "falara com todo o mundo em Washington e ninguém sabe que a América Latina existe". BERLE, Beatrice \& JACOB, Travis B. Navigating the rapids, 1918-1971: From the papers of Adolf A. Berle. Nova Yorque, 1973. p. 587

22 Memorandum do Departamento de Estado. Arquivo Geral do Departamento de Estado. 27 jun. 1949, maco 832.00/6 1979. Ministério das Relacões Exteriores a Johnson. Arquivo Macedo Soares. 12 jan. 1950: JOHNSON a KENNAN, George. Arquivo Johnson. (caixa 6), 3 abr. 1950; Foreign Relations of the United States, 1950. Washington, 1976-1978. v. 2, p. 757

23. Responderia à nota americana "oportunamente, como exige a dignidade do modesto porém brioso Ministério do Exterior brasileiro" escreveu Raul Fernandes. FERNANDES, Raul. Arquivo Macedo Soares. 22 ago. 1950.

24. ACHESON, Dean. Memorandum. Arquivo Dean Acheson. Biblioteca Harry S. Truman. (caixa 65), 24 abr./1 maio 1950. Foreign Relations of the United States, 1950. Washington. v. 12, 713-14. Os estudos técnicos básicos para o empréstimo argentino, confessou um assessor de John Snyder, tinham sido "quase integralmente" preparados em Washing ton. COURANC, Claude a JOHNSON. Arquivo Johnson. (caixa 3) 21 maio 1950. O governo argentino, desse modo, fora ajudado para evitar a acusação que freqüentemente era feita às autoridades brasileiras - a apresentação incorreta de informações técnicas.

25. NABUCO, Joaquim a FERNANDES, Raul. Arquivo Histórico do Itamarati, 12 maio 1950; JOHNSON a COURANC. Arquivo Johnson. (caixa 3), 27 jun. 1950. FERNANDES, Raul a NABUCO, Joaquim. Arquivo Histórico do Itamarati. 15 maio 
1950. JOHNSON ao Departamento de Estado. Arquivo do Departamento de Estado. Washington, Departamento de Estado. 25 ago. 1950 , maço $611.32 / 8-2550$.

26. O Jornal. 6 jun. 1950; Correio da Manhã, 11 jun. 1950; Memorandum do Departamento de Estado. Arquivo Acheson. (caixa 65), 19 jun. 1950. NABUCO, Joaquim ao Ministério das Relaçðes Exteriores. Arquivo Histórico do Itamarati. 19-21-26 jun. 1950; JOHNSON ao Departamento de Estado. Arquivo do Departamento de Estado. Washington, Departamento de Estado. 25 ago. 1950, maço 611.32/8-2550.

27. FERNANDES, Raul a DUTRA, Eurico Gaspar. Coleção Presidência da República. 5 set. 1950. "Com relação ao Brasil, a importância que eles atribuem a nossa eventual participação na defesa da Coréia é acentuada". "NABUCO, Joaquim a FERNANDES, Raul. Arquivo Histórico do /tamarati. 14 ago. 1950.

28. NABUCO, Joaquim ao Ministério das Relaçðes Exteriores. Arquivo Histórico do /tamarati. 25 jul. 1950.

29. Foreign Relations of the United States, 1950. Washington, v. 2, p. 761

30. Ver, por exemplo, Correio da Manhã. 28, 29 e 30 jun. 1950.

31. NABUCO, Joaquim ao Ministério das Relaçðes Exteriores. Arquivo Histórico do /tamarati. 20 jul. 1950.

32. Jornal do Comércio. Rio de Janeiro. 2 jul. 1950; JOHSON ao Departamento de Estado. Arquivo do Departamento de Estado. 5 jul. 1950, maço 611.32/7-550.

33. FERNANDES, Raul a DUTRA, Eurico Gaspar. Coleção Presidencia da República. 5 set. 1950; Conselho de Segurançpa Nacional a DUTRA, Eurico Gaspar. Coleção Presidência da República. 23 nov. 1950; NABUCO, Joaquim ao Ministério das Relaçסes Exteriores. Arquivo Histórico do Itamarati. 2 ago. 1950.

34. FERNANDES, Raul a JOHNSON. Arquivo Macedo Soares. 22 ago. 1950.

35. NABUCO, Joaquim ao Ministério das Relaç̃es Exteriores. Arquivo Histórico do Itamarati. 25 ago. 1950. FERNANDES. Raul a DUTRA, Eurico Gaspar. Coleção Presidência da República. 17 out. 1950. Foreign Relations of the United States, 1950. Washington v. 1, p. 649,655-56. v. 2, p. 763-71, 774-75.

36. Foreign Relations of the United States, 1950. Washington. v. 12, p. 775-77; ACHESON. Memorandum. Arquivo Acheson. (caixa 65), 19 out. 1950. FERNANDES, Raul a DUTRA, Eurico Gaspar. Coleção Presidéncia da República. 17 out. 1950.

37. Foreign Relations of the United States, 1950. Washington, v. 1. p, 675; NABUCO, Joaquim ao Ministério das Relaçes Exteriores. Arquivo Histórico do /tamarati. 1 dez. 1950; Ministério das Relaçరes Exteriores a NABUCO, Joaquim. Arquivo Historico do Itamarati. MILLS, Sheldon a JOHNSON. Arquivo Johnson. (caixa 8), 8 dez. 1950; NABUCO, Joaquim ao Ministério das Relaçరes Exteriores. dez. 21, 1950. Arquivo Historico do /tamarati. 21 dez. 1950. MILLER, Junior Edward G. a DONNELLY, Walter. Arquivo Edward G. Miller Jr. Bibilioteca Harry S. Truman. 13 dez. 1950. Foreign Relations of the United States, 1951: Washington, 1977-79, v. 12, p; 1189.

38. Pronunciamento do Secretário Acheson, dez. 16, 1950. Department of State Bulletin, 24(8), 1 jan. 1951. 8; Memorandum do Departamento de Estado, Arquivo do Departamento de Estado, maço 611.32/12-1850. $18 \mathrm{dez}$. 1950; JOHNSON a FONTOURA, João Neves. Arquivo de Getúlio Vargas. Centro de Pesquisa e Documentação de Histórica Contemporânea. 29 dez. 1950.

39. FONTOURA, João Neves a ARANHA, Oswaldo. Arquivo Aranha. 9-15 jan. FONTOURA, João Neves a VARGAS, Tetúlio. Arquivo Vargas. 11 jan. 1951; FONTOURA, João Neves a JOHNSON. Arquivo Vargas. 13 jan. 1951. Uma tradução inglesa da última consta de Foreign Relations of the United States, 1951. Washington v. 12, p. 1184-88.
40. Foreign Relations of the United States, 1951. Washington. p. 1991-97, 1190-1; Memorandum do Ministério das Relaçðes Exteriores. Arquivo Historico do Itamarati, 19 fec. 1951; FONTOURA, João Neves a VARGAS, Getúlio. Arquivo Getúlio Vargas. 19,21, 24 fev. 1951. Quanto à argumentaçăo dos estrategistas políticos e econômicos brasileiros de que o governo agisse cautelosamente até que sues necessidades econômicas essenciais tivessem sido atendidas, ver Ata do Conselho Nacional de Economia. fev. 22, 1951. Arquivo do Conselho Nacional de Economia. Rio de Janeiro, Arquivo Nacional. (caixa 20), 22 fev. 1951. Memorandum do Ministério das Relaçoses Exteriores. Arquivo Historico do ltamarati. $19 \mathrm{fev}$. 1951. FONTOURA, João Neves a VARGAS, Getúlio. Arquivo Vargas. 19, 21 e 24 fev. 1951.

41. FONTOURA, João Neves a VARGAS, Getúlio, Arquivo Vargas. 16 mar. 1951. FONTOURA, João Neves ao Ministério das Relaçర̃es Exteriores. Arquivo Histórico do /tamarati, 28 mar. 1951. João Neves tinha sido convidado para responder ao discurso de Truman na sessão de abertura. Acheson havia insistido com Truman para que falasse, na esperança de convencer os governos latino-americanos a acompanharem o programa de mobilização dos Estados Unidos. Joåo Neves, mais tarde, declarou a uma comissão parlamentar no Brasil que ficara "terrivelmente angustiado" enquando redigia seu discurso pois teria que contestar publicamente a politica dos Estados Unidos, coisa que nenhum Ministro do Exterior brasileiro jamais fizera em uma reunião interamericana. ACHESON, Dean a TRUMAN, Harry S. Arquivo Truman. of 187-A. Ministério das Relaç̋es Exteriores. Exposição do Ministro Joåo Neves da Fontoura aos Membros das Comissర్s de Relaçøes Exteriores do Senado Federal e de Diplomacia e Tratados da Câmara dos Deputados e aos Líderes aos Partidos Nacionais com Assento no Parlamento, em 29 de maio de 1951. Rio de Janeiro. 1951, p. 33.

42. Foreign Relations of the United States, 1951. Washington, v. 2 , p. $964,1005,1009$. FONTOURA, Joăo Neves ao Ministério das Relaçøes Exteriores. Arquivo Histórico do Itamarati. 4 abr. 1951.

43. FONTOURA, Jão Neves, FONTES, Lourival. Arquivo Vargas. 28 mar. 1951. Memoranda da Delegação do Brasil à Conferência de Washington. Arquivo Histórico do Itamarati. 31 mar. /3abr. 1951. FONTOURA, Jão Neves a VARGAS, Getúlio. Arquivo Histórico do ltamarati. 1. 3 abr. 1951: ACHESON, Dean. Present at the creation: my years in the State Department. Nova lorque, 1969, p. 1497

44. NABUCO, Joaquim ao Ministério das Relaçðes Exteriores. Arquivo Histórico do Itamarati. 1 jul. 1951. Foreign Relationsof the United States, 1951. v. 2. p. 1204-04; COUTINHO, Lourival. o General Góes depסe. Rio de Janeiro, 1956. p. 517-18; VARGAS, Getúlio a FONTES, Lourival. IN: FONTES, Lourival \& CARNEIRO, Glauco. A Face final de Vargas. Rio de Janeiro 1966. p. 74, jul. 1951. Memorandum do Ministério das Relaçסes Exteriores. Arquivo Vargas. jul. 1951

45. Foreign Relations of the United State, 1951. Washington. v. 12. p. 1197-98, 1200, 1205-06, 1211, 1229; NABUCO, Joaquima GOES, Monteiro. Arquivo Histórico do Itamarati. 27 jul. 1951. GOES, Monteiro a VARGAS, Getúlio, Arquivo Vargas. 30 jul. 1951; GOES, Monteiro a ARANHA, Oswaldo. Arquivo Arantha. 3 ago. 1951. Memorandum de Acheson. Arquivo Acheson. (caixa 66), 15 out. 1951.

46. Foreign Relations of the United States, 1951. Washington v. $12,1022-32$; FONTOURA, João Nevesa VARGAS, Getúlio, Coleção Presidência da República, 25 mar. 1952. Acordos de Assistência Militar. Department of State Bulletin. 24: 450, 24 mar. 1952.

47. MILLER a BROOKS, A. Oakley. Arquivo Miller. (caixa 1), 16 maio, 1951. LAFER, Horácio a VARGAS, Getúlio. IN: Getúlio Vargas, O Governo trabalhista do Brasil. No Rio de Janeiro, 1952-1969: v. 3, p. 98, 6 fev. 1952; WIRTH, John D. The Politics of brazilian development, 1930-1954. Stanford, 1970. p. 184-96; 
SMITH, Peter Seapom. Oiland politics in modern Brazil. Toronto, 1976. p. 79-82.

48. BOHAN, Marwin a MANN, Thomas. Arquivo Merwin Bohan. Biblioteca Harry S. Truman. (caixa 7), 29 jan. 1953.

49. MILLER a ACHESON, Dean. Arquivo Acheson. (caixa 67), 22 bar. 1952. FURTADO, João Neves a VARGAS, Getúlio. Arquivo Vargas. 9 jun. 1952; SALLES, Walter Moreira a FONTES, Lourival. Arquivo Vargas. 10 out. 1952. ACHESON, Dean. Present at the creation. p. 666-68; VARGAS, Getúlio. Mensagem ao Congresso, 1952. Rio de Janeiro, 1952. p. 26, 29; FURTADO. João Neves. IN: News York Times. 24 abr. 1952.

50. FURTADO, João Neves a VARGAS, Getúlio. Arquivo Vargas, 10, 21 nov. 1952. SKIDMORE, Thomas E. Politics in Brazil, 1930-1964: an experiment in democracy. Nova lorque, 1967. p. 115-65; MALAN, Pedro et alii. Política econômica externa e industrialização no Brasil, 1939-52. Rio de Janeiro, 1977, p. 165, 192.

51. EISENHOWER, Dwight D. Mandate for change, 1953-1956. Garden City, 1963. p. 135-136. DULLES, John Foster, Memoranda telefônica. Arquivo John F. Dulles. Texas, Biblioteca Dwight D. Eisenhower, Abilene. (caixa 1), 19, 20 fev. 1953.

52. SALLES, Moreira ao Ministério das Relaç̃es Exterioreś. Memoranda telefônica. Arquiṽo Vargas Dulles. (caixa 1), 20 fev. 1953. EISENHOWER, Dwight. Mandate for change, 136; Brazilian loan agreement. Department of State Bulletin. 28: 754, 25 maio 1953. JOHNSON a JAMISON, Edward. Arquivo Johnson. (caixa 6), 7 maio 1953.

53. BOHAN, Marwin a MANN, Thomas. Arquivo Bohan. Icaixa 7), 29 jun. 1953; DULES, John Foster. Memoranda telefônica. Arquivo Dules. (caixa 1), 20 fev. 1953. DULES, John Foster a ElSENHOWER, Dwight. Arquivo Dwight D. Eisenhower. Biblioteca Eisenhower; pasta Brazil 13 (caixa 4) 4 mar. 1953; BRANDÃO, Carlos a FURTADO, João Neves. Arquivo Vargas. 4 mar. 1953; EISENHOWER, Milton S. The wine is bitter: the United State and Latin America. Garden City, 1963, p. 7.

54. FURTADO, João Neves a VARGAS, Getúlio. Arquivo Vargas, 16 abr. 1953. VARGAS, Getúlio a EISENHOWER, Dwight. Arquivo Vargas. 17 abr. 1953; PEIXOTO, Alzira Vargas do Amaral a VARGAS, Getúlio, Arquivo Bohan. (caixa 7), 28 abr. 1953; FURTADO, João Neves, citado por FIGUEIREDO, M. Poppe de. IN: Brasil: um gigante que despertou, Rio de Janeiro, 1972, p. 211; DULES John Foster a VARGAS, Getúlio. O Estado de São Paulo. 312. 7 jun. 1953.

55. EISENHOWER, Dwight. The Wine is bitter: the United States and Latin America. p. 152; EISENHOWER, Dwight a VARGAS, Getúlio. Arquivo Vargas, 22 jun. 1953; Ata de reunião ministerial, série Gabinete. Arquivo Eisenhower. (caixa 2), 3 jul. 1953; Milton a EISENHOWER, Dwight. Arquivo Eisenhower. 9 out. 1953.

56. Ata de reunião ministerial, série Gabinete, Arquivo Eisenhower. (caixa3), 26 fev. 1954

57. KAPLANe BONSOR. Did United States aid realy help Brazilian development? p. 28. Em 1953, o Brasil recebera do Banco de Exportação e Importação, além de um empréstimo para pagamento de atrasados comerciais, US 200 Milhøes adicionais mas um terço desta importância fora concedido a uma corporaçăo mineradora de manganês, da qual a Bethlehem Steel era acionista, para permitir um aumento de produção cujo resultado se. destinava ao mercado americano. New Manganese project undertaken in Brazil. Department of State Bulletin. 27: 140, 26 jan. 1953.

58. ARANHA, Oswaldo a VARGAS, Getúlio. Arquivo Vargas. jul. 1953. Correio da Manhã. 27 nov., 1953; GUILLOBEL, Renato. Ao Chefe da Missão americana. 4 ago. 1953; GUILLOBEL, Renato. Memórias. Rio de Janeiro, 1973. p. 541-42.

59. FURTADO, João Neves a VARGAS, Getúlio. mar. 10, 1952,
Coleção Presidência da República; Comércio com a Alemanha Conjuntura Econômica. 11: 35, maio 1957; RAO, Vicente a VARGAS, Getúlio. Coleção Presidência da República. 13 jul. 1954.

\section{HILTON. Brazil and the post-Versailles world. p. 357-58.}

61. Atlas do Conselho Nacional de Economia. Arquivo do Conselho Nacional de Economia. (caixa 220-222), 24-26 jul. 1951, 12 set. 1952.

62. DANTAS, Francisco San Tiago a VARGAS, Getúlio. Arquivo Vargas, 27 bar. 1951; Jornal do Comércio, 2 jan. 1952.

63. RIBEIRO, Orlando Leite a VARGAS, Getúlio. Arquivo Vargas. 15 jun. 1954. CAFÉ FILHO, João. Memórias políticas e confissões humanas, Rio de Janeiro, 1966, v. 1, p. 272-73. Getúlio Vargas, durante seu último ano de governo, começou a falar da solidariedade latino-americana com vistas ao desenvolvimento. VARGAS, Getúlio. O governo trabalhista. v. 4, p. 40-42; VARGAS, Getúlio. Mensagem ao Congresso Nac:ional... 1954. v. 8.

64. CAFÉ FILHO, João a EISENHOWER, Dwight D. Set. 1954; EISENHOWER. Dwight a CAFÉ FILHO, João. Arquivo Central da Casa Branca, Arquivo Eisenhower. pasta of. 164 Brasil 1 lcaixa 854) 8 out. 1954 .

65. LOTT, Henrique a CAFÉ FILHO, João. Arquivo João Café Filho. Centro de Pesquisa e Documentaç̃es de História Contemporânea. pasta 13/1, 16 nov. 1954. Atas de reuniões Ministeriais, série Gabinete. Arquivo Eisenhower. 3 dez. 1954

66. FERNANDES, Raul a MUNIZ. Arquivo Café Filho. pasta 4,6 jan. 1955; MUUNIZ a FERNANDES, Raul. Arquivo Café Filho. 3 fev. 1955. MUNIZ a ADAMS, Sherman. Arquivo Central da Casa Branca. Arquivo Eisenhower. pasta of. 164, Brasil 1 (caixa 854), 13 maio 1955.

\section{Ver, por exemplo Correio da Manhã. 29 set. 1955}

68. Memorandum do Departamento de Estado. Arquivo Central da Casa Branca. Arquivo Eisenhower. pasta of. 164, Brasil 2 (caixa 854) 15 dez. 1955; DULES, John Foster a EISENHOWER, Dwight. Arquivo Whitman. pasta Brasil 10 (caixa 4), 4 jan. 1956.

69. Memorandum do Ministério das Relações Exteriores. Arquivo Macedo Soares. dez. 1955 -jan. 1956.

70. Memorandum do Ministério das Relações Exteriores. Arquivo Macedo Soares. jan. 1956.

71. Memorandum do Ministério das Relações Exteriores, Arquivo Macedo Soares. 2 fev. 1956. Discurso de Juscelino Kubistchek, IN: KUBISTCHEK, Juscelino a EISENHOWER, Dwight. Arquivo Central da Casa Branca. Arquivo Eisenhower. of. BrasiL 2 (caixa 854), 28 abr. 1956. EISENHOWER, Dwight a KUBISTCHEK, Juscelino. Arquivo Central da Casa Branca. Arquivo Eisenhower. of Brasil 2 (caixa 854), 8 maio, 1956. DULLES. John Foster a EISENHOWER. Dwight. Arquivo Whitman. pasta Brasil 9 (caixa 4), 30 abr. 1956. EISENHOWER, Dwight. PINHEIRO, João Baptista. Memorandum. Arquivo Macedo Soares. 7 jun. 1956.

72. OLIVEIRA, Antônio Camillo de. Palestra. Escola Superior de Guerra. 8 jun. 1956. Arquivo Aranha. C-48-56.

73. MUNIZ a DULES, John Foster. Arquivo Macedo Soares. 19 mar. 1956. MACEDO, Soares a BRIGGS, Ellis. Arquivo Macedo Soares. 9 set. 1956.

74. BRIGGS, Ellis ao Departamento de Estado. Arquivo do Departamento de Estado. 19, $28 \mathrm{dez}$. 1956. Ministério das Relações Exteriores ao Departamento de Estado. Arquivo Macedo Soares. 14 jan. 1957. KUBISTCHEK, Juscelino a EISENHOWER, Dwight. Arquivo Whitman. Arquivo Eisenhower. pasta Brasil 8 (caixa 4), 2 fev. 1957. PEIXOTO, Ernani do Amaral ao Departamento de Estado. Arquivo Macedo Soares. 6 nov. 1958.

75. LEITE FILHO, João Barreto. Palestra. Escola Superior de Guerra. Arquivo Aranha. C 37-56, maio 1956. MELLO, Vieira de. 
Discurso. Arquivo Macedo Soares. 11 jul. 1956. MORAES, Armando. Palestra. Escola Superior de Guerra. Arquivo Oswaldo Aranha. 22 ago. 1956. C76-56. ARANHA. Oswaldo a SOARES, Macedo. Arquivo Macedo Soares. 21 out. 1957. CAMARA FILHO, José Sette. Palestra. Escola Superior de Guerra. Arquivo Aranha. maio 1958, C 1-41-58. MUNIZ. Palestra. Escola Superior de Guerra. Arquivo Oswaldo Aranha. maio 1958, E.S.G. C50-58.

76. O Estado de São Paulo. 19 jan., 1957; O Globo. Rio de Janeiro 20, 22 maio, 1958; Diário de São Paulo. 22, 29jun. 1958. A imprensa nacionalista de esquerda estava dizendo a mesma coisa. Compare Uiltima Hora. Rio de Janeiro. 13 jan., 28 abr. e 26 maio 1958.

77. Departamento de Estado a EISENHOWER, Dwight. Arquivo Central da Casa Branca, Arquivo Eisenhower. pasta of. Brasil 3 (caixa 854), 15 out. 1957. Ata de reunião ministerial. Série Gabinete. (caixa 11), 16 maio 1958. EISENHOWER, Dwight. Memorandum do Departamento de Estado. Arquivo Whitman. pasta Argentina 5 (caixa 1), 23 jun

78. KUBISTCJEK, Juscelino. Discurso-1956, p. 219; KUBISTCHEK, Juscelino. Discurso-1957. Rio de Janeiro, 1958. p. 54; KUBISTCHEK, Juscelino. Mensagem ao Congresso Nacional... 1958. Rio de Janeiro, 1958. p. 60-61; Ministério das Relações Exteriores. Relatório... 1956. Rio de Janeiro, 1956; Ministério das Relaç̃̃es Exteriores. Relatório... 1957. Rio de Janeiro; O Estado de São Paulo. 29 ago., 7 dez. 1957; MOURA, Decio. Palestra. Escola Superior de Guerra. Arquivo Macedo Soares. 31 out. 1957; CAMARA FILHO, José Sette, Palestra. Escola Superior de Guerra. Arquivo Macedo Soares. C1-45-58, maio 1958. Palestra. Escola Superior de Guerra. Arquivo Macedo Soares. E.S.G. C-50-58, maio 1958.

79. PINTO, Luis Bastian. Palestra. Escola Superior de Guerra Arquivo Macedo Soares. E.S.G. C1-51-58, maio 1958. O Presidente do Conselho Nacional de Economia focalizou o mesmo aspecto. TORRES, José Garrido. Porque um mercado regional latino-americano?. Revista Brasileira de Politica Internacional, 1:114-18.

80. KUBISTCHEK, Juscelino. Por que construi Brasilia. Rio de Janeiro, 1976. p. 14-42. Quanto a críticas anteriores de Augusto Frederico Schmidt à Politica dos Estados Unidos, ver seus artigos no $O$ Jornal, 17 out. 1948 e Correio da Manhã. 8 set. 1948, 15, 25 e 26 jan., 21 out. 1949 e 29 jun. 1950. Sobre a viagem de Richard M. Nixon ver NIXON, Richard M. Six crises. Nova lorque, 1962. p. 183-234
81. KUBISTCHEK, Juscelino. Porque construí Brasilia. p. 157$59,195$.

82. DULLES, John Foster e EISENHOWER, Dwight. Memoranda telefônica. Arquivo Dulles. 6 jun. 1958. EISENHOWER, Dwight a KUBISTCHEK, Juscelino. Arquivo Whitman, Arquivo Eisenhower. pasta Brasil 8 (caixa 4), 5 jun. 1958. KUBISTCHEK, Juscelino. Por que construi Brasilia. p. 153, 155-57, 160-61; BRIGGS a SOARES, Macedo. Arquivo Macedo Soares. jun. 1958. Sobre a viagem de DULLES, John Foster ver também DULLES, Eleonor Lansing. John Foster Dulles; The Last year. Nova York, 1963. p. 152.

83. BRIGGS para o Departamento de Estado. Arquivo do Departamento de Estado. maço 611.32/1-1959. 19 jan. 1959. PAARLBER, Don. a WHITMAN, Ann. Arquivo Eisenhower. pasta Notas de Assessores, 2 (caixa 39), série do Diário. 1-15 mar. 1959.

84. KUBISTCHEK, Juscelino. Mensagem ao Congresso Nacional. IN: Abertura da Sessão Legislativa de 1959. Rio de Janeiro, 1959. p. 11; O Estado de São Paulo. 1 maio 1959 e no Jornal do Brasil, 5 nov. 1959.

85. Embaixada dos Estados Unidos no Rio de Janeiro ao Departamento de Estado. dez. 14, 1959. Arquivo do Departamento de Estado. $14 \mathrm{dez}$. 1959. EISENHOWER, Dwight. Waging Peace, 1956-61. Nova lorque, 1965. p. 525-32; KUBISTCHEK, Juscelino a EISENHOWER, Dwight. Arquivo Whitman. Arquivo Eisenhower. pasta Brasil 3 (caixa 4), 13 jan. 1960: Memorandum do Departamento de Estado. Arquivo Whitman. Arquivo Eisenhower. pasta Brasil 3 (caixa 4), 18 mar. 1960. KUBISTCHEK, Juscelino a EISENHOWER, Dwight. Arquivo Whitman, Arquivo Eisenhower. pasta Brasil 3 (caixa 4), 19 jul. 1960.

86. KUBISTCHEK, Juscelino. Porque construi Brasilia. p. $197-$ 207-08.

87. Embaixada dos Estados Unidos no Rio de Janeiro ao Departamento de Estado. Arquivo do Departamento de Estado. 1 set. 1960.

88. MUNIZ; João Carlos. Significado da Operação PanAmericana. Revista Brasileira de Política Internacional. 2: 11, set. 1959; MENEZES, Adolpho. Palestra. Escola Superior de Guerra (1960). Rio de Janeiro, Escola Superior de Guerra. Biblioteca do Exército C!42-60; VALLE, Henrique Rodrigues. Palestra. Escola Superior de Guerra, ago. 1960. Rio de Janeiro, Escola Superior de Guerra. Biblioteca do Exército C-46-60.

89. SELCHER , Wayne A. The Afro-Asian dimension of Brazilian foreign policy, 1856-1972. Gainesville, 1974. 